\title{
Identification of food sources of invertebrates from the seagrass Zostera marina community using carbon and sulfur stable isotope ratio and fatty acid analyses
}

\author{
V. I. Kharlamenko*, S. I. Kiyashko**, A. B. Imbs, D. I. Vyshkvartzev \\ Institute of Marine Biology, Far East Branch, Russian Academy of Sciences, Vladivostok 690041, Russia
}

\begin{abstract}
Carbon and sulfur stable isotope ratios, as well as fatty acid composition of tissues, of dominant consumer species were determined and compared to those of potential food sources in an isolated community of Zostera marina in a shallow, semi-enclosed inlet of the Sea of Japan. Of the 6 dominant species of invertebrates, 4 species were enriched in ${ }^{13} \mathrm{C}$, compared to all sampled carbon sources alternative to $Z$. marina. Among them, the grazing gastropods Littorina squalida and Homalopoma sangarense exhibited the most enriched $\delta^{13} \mathrm{C}$ values. On the dual $\delta^{13} \mathrm{C}$ versus $\delta^{34} \mathrm{~S}$ plot, these mollusks occupy an intermediate position between $Z$. marina and epiphytes, suggesting nearly equal proportions of organic carbon from both nutritional sources. In lipids of $H$. sangarense there was a high content of the 18:1(n-7) acid characteristic of aerobic bacteria; however, another grazer (L. squalida) showed the lowest content of bacterial fatty acids among all consumers. Other highly ${ }^{13} \mathrm{C}$-enriched consumers were the surface-deposit-feeding mollusks, the gastropod Batillaria cumingii and the bivalve Macoma incongrua; however, their $\delta^{34} \mathrm{~S}$ values were markedly lower than those of any of the primary producers sampled, including $Z$. marina. Although the high $\delta^{13} \mathrm{C}$ values of grazers and surface-deposit feeders are suggestive of a great contribution of $Z$. marina organic carbon, no substantial concentrations of seagrass marker fatty acids were detected. Significant interspecific variations of both the sulfur isotope ratios and the fatty acid composition of these consumers suggest that there are a variety of pathways by which seagrass organic matter reaches invertebrates at lower trophic levels of the community food web. Dominant filter feeders, the bivalves Ruditapes philippinarum and Pillucina pisidium, had carbon drastically different in isotopic composition from $Z$. marina organic matter. Body tissues of $P$. pisidium and especially its gills, which bear symbiotic bacteria, were dramatically depleted both in ${ }^{13} \mathrm{C}$ and ${ }^{34} \mathrm{~S}$ compared to all sources of photosynthetically fixed carbon in the bay. Very low $\delta^{13} \mathrm{C}$ and $\delta^{34} \mathrm{~S}$ values of $P$. pisidium body together with a high content of 18:1(n-7) acid suggest a leading role of sulfur-oxidizing symbiotic bacteria in the nutrition of this species. R. philippinarum was only slightly ${ }^{13} \mathrm{C}$-enriched, compared to $\mathrm{POM}$, and was the only consumer which had the high concentration of fatty acids characteristic of plankton, particularly $22: 6(n-3)$. At the same time, it was much more ${ }^{34}$ S-depleted than would be expected, assuming negligible contribution of $Z$. marina detritus to its food. This mollusk showed a high content of branched fatty acids, especially the iso17:0 and anteiso17:0 acids characteristic of bacteria from sediment; this suggests that $R$. philippinarum assimilated notable amounts of bacteria from resuspended sediment. Furthermore, the contribution of ${ }^{34} \mathrm{~S}$-depleted bacteria, which inhabit reduced sediment, to $R$. philippinarum nutrition was high enough to result in the observed depletion of ${ }^{34} \mathrm{~S}$ in mollusks. Further progress in food web studies of seagrass ecosystems using a complex of multiple stable isotope and fatty acid analyses would appear possible on the basis of analysis of separate components of the seagrass epiphytic community and micro- and meiobenthic organisms, inhabiting surface sediments.
\end{abstract}

KEY WORDS: Eelgrass community $\cdot$ Mollusks $\cdot$ Stable carbon isotope $\cdot$ Stable sulfur isotope $\cdot$ Fatty acids $\cdot$ Food web

Resale or republication not permitted without written consent of the publisher

\section{INTRODUCTION}

*Present address: Kamchatka Research Institute of Fisheries and Oceanography, Naberegnaya 18, Petropavlovsk-Kamchatsky 683002, Russia

${ }^{* *}$ Corresponding author. E-mail: sekiyash@hotmail.com
Seagrass communities are widely distributed in marine shallow water all over the world and are among the most productive marine ecosystems (McRoy \& 
McMillan 1977, Zieman \& Wetzel 1980, Duarte 1989). Live tissues of marine vascular plants are of limited use as food for animals; therefore, other primary producers or the detrital food chain supports secondary production in these communities (Mann 1972, Fenchel 1977, Kikuchi 1980). A number of constraints (small size of some consumers, impossibility of identifying a number of primary producers and intermediate links in the food web) have compelled investigators to abandon gut analysis methodology and have led to a use of a variety of other methods, including stable isotope ratio analysis (SIRA), to determine seagrass community food webs (Klump et al. 1989).

The contribution of seagrass organic matter to food webs can be estimated by carbon $\left({ }^{13} \mathrm{C} /{ }^{12} \mathrm{C}\right)$ SIRA of the consumers, since seagrasses and other primary producers in communities usually differ in the isotopic composition of organic carbon (Thayer et al. 1978, McConnaughey \& McRoy 1979, Fry et al. 1987, McClelland \& Valiela 1998). Because little change occurs in the ${ }^{13} \mathrm{C} /{ }^{12} \mathrm{C}$ ratio on each trophic level (DeNiro \& Epstein 1978), it is possible to identify in animal tissues the proportion of carbon originally synthesized by seagrass; however, it is impossible to follow the pathway by which it enters the consumers. Moreover, if organic matter is derived from more than 2 sources, additional information is needed for unambiguous estimation of the contribution of each source to the food web by carbon SIRA (Fry \& Sherr 1984). Sulfur $\left({ }^{34} \mathrm{~S} /{ }^{32} \mathrm{~S}\right)$ SIRA could significantly improve the method (Fry et al. 1987), but appears not to have been attempted in seagrass systems (Hemminga \& Mateo 1996).

The sulfur SIRA has been widely used to examine organic matter flows in saltmarsh food webs (Peterson et al. 1985, 1986, Sullivan \& Moncreiff 1990, Currin et al. 1995). Marine vascular plants deeply rooted in reduced sediments are considerably ${ }^{34} \mathrm{~S}$-depleted compared to algae, due to incorporation of ${ }^{34} \mathrm{~S}$-depleted sulfides (Fry et al. 1982, Trust \& Fry 1992). This allows the use of $\delta^{34} \mathrm{~S}$ as a marker in the analysis of the fate of organic matter synthesized by vascular plants in the near-shore zone (Newell et al. 1995, Deegan \& Garritt 1997, Stribling \& Cornwell 1997). The fact that eelgrass Zostera marina is also ${ }^{34} \mathrm{~S}$-depleted (Mekhtieva et al. 1976), compared to marine algae, encourages us to believe that the stable sulfur isotope ratio will be useful as a second isotope marker in eelgrass community food webs.

Using SIRA alone, it is difficult to assess the contribution of the main component of the detritus food chain - heterotrophic microorganisms; hence, in addition to isotopes, lipid markers were used. Bacteria, microalgae, macroalgae and seagrasses contain different specific fatty acids. The presence of these specific fatty acids in the animal tissues may indicate which organisms are food items for a given animal (Sargent \& Whittle 1981). However, a combination of carbon SIRA and lipid markers has rarely been used for analyzing trophic relationships in seagrass meadows (Nichols et al. 1985, 1986) or other marine environments (Canuel et al. 1995).

In this work, we have made an attempt to identify the major food sources of the dominant invertebrate species in a relatively isolated Zostera marina meadow in the shallow, semi-enclosed inlet of the Sea of Japan, using a combination of carbon and sulfur SIRA and lipid markers. With this aim in view, carbon and sulfur stable isotope ratios, as well as the fatty acid composition, of tissues of the dominant invertebrate species were determined and compared with the same variables in the potential food sources.

\section{MATERIALS AND METHODS}

Study area and sample collection. The study was carried out in microtidal Novgorodskaya Bight (Possyet Bay, Sea of Japan). This bight has no marked runoff of freshwater. The broad, semi-enclosed inward part of the bight communicates with the rest of the bay through a shallow channel. The water depth in the inward part does not exceed $3.6 \mathrm{~m}$, and at this location most of the bottom area (about $15 \mathrm{~km}^{2}$ ) is covered by a subtidal Zostera marina meadow (Fig. 1). The results of intensive hydrobiological studies of this community (Vyshkvartzev \& Peshekhodko 1982, Lebedev \& Vyshkvartzev 1988, 1990) indicated that Z. marina comprises $83 \%$ of the total community biomass in this part of the bight, followed by the seagrass $Z$. japonica and the green alga Codium fragile $(4 \%$ and $2 \%$, respectively). Animals represent $11 \%$ of the total community biomass, and only 6 species of invertebrates comprise $>90 \%$ of the macrozoobenthic biomass. All of the most abundant species are bivalves and gastropods, with different modes of feeding (Table 1). They were selected for the study of the isotope and fatty acid composition of the community's main consumers.

Samples for analysis were collected in July 1996 by SCUBA diving. All samples of macrophytes and consumers were collected in the same area (150 to $200 \mathrm{~m}^{2}$ ) at a distance of $160 \mathrm{~m}$ from the shore and at a depth of $2 \mathrm{~m}$, in order to minimize the spatial differences in the food supply of animals.

All animal and plant samples for SIRA and lipid analysis consisted of at least 10 individuals of the same species that had been collected concurrently at the same site. For the food web studies by SIRA and lipid analysis, when high cost of analyses allows only low replication, such pooling of samples has the advantage 
of reducing intraspecific variability in the signals of isotopic and lipid markers.

During the sampling period, there were only 3 major sources of plant material in the investigated community: eelgrass, epiphytic algae and phytoplankton. The Novgorodskaya Bight has no direct river or creek drainage; therefore, terrestrial plant material is not a major source. Microscopic examination of the top layer of bottom sediment using epifluorescent microscopy at a magnification of $200 \times$ revealed no notable amount of benthic microalgae or terrestrial plant detritus. The macroalga Codium fragile was found mainly outside the eelgrass community, at a distance $4 \mathrm{~km}$ from the sampling plot.

Composite samples of Zostera marina comprised green leaves, old brown leaves and rhizomes, which were pooled separately. Fallen decomposing leaves were collected from the bottom. The leaf blades were carefully cleared of epiphytes using a razor blade.

Total samples of epiphytic algae were collected from mature green leaves using a razor blade. Samples were examined using microscope for detection of seagrass debris, which was then removed.

Suspended particulate organic matter (POM) was collected from the water column with a net (mesh size $150 \mu \mathrm{m})$ directly above the Zostera marina bed. The net tow samples from the $Z$. marina meadow consisted mainly of zooplankton, primarily copepods.

Samples of benthic POM from the sediment-water interface were collected using a vacuum sampling device (Levin 1987). A subsample of small particles of Zostera marina detritus was selected for lipid analysis from these samples using a stereo microscope. Samples of the top $1 \mathrm{~cm}$ of sediment were collected with a glass tube $5 \mathrm{~cm}$ in diameter.
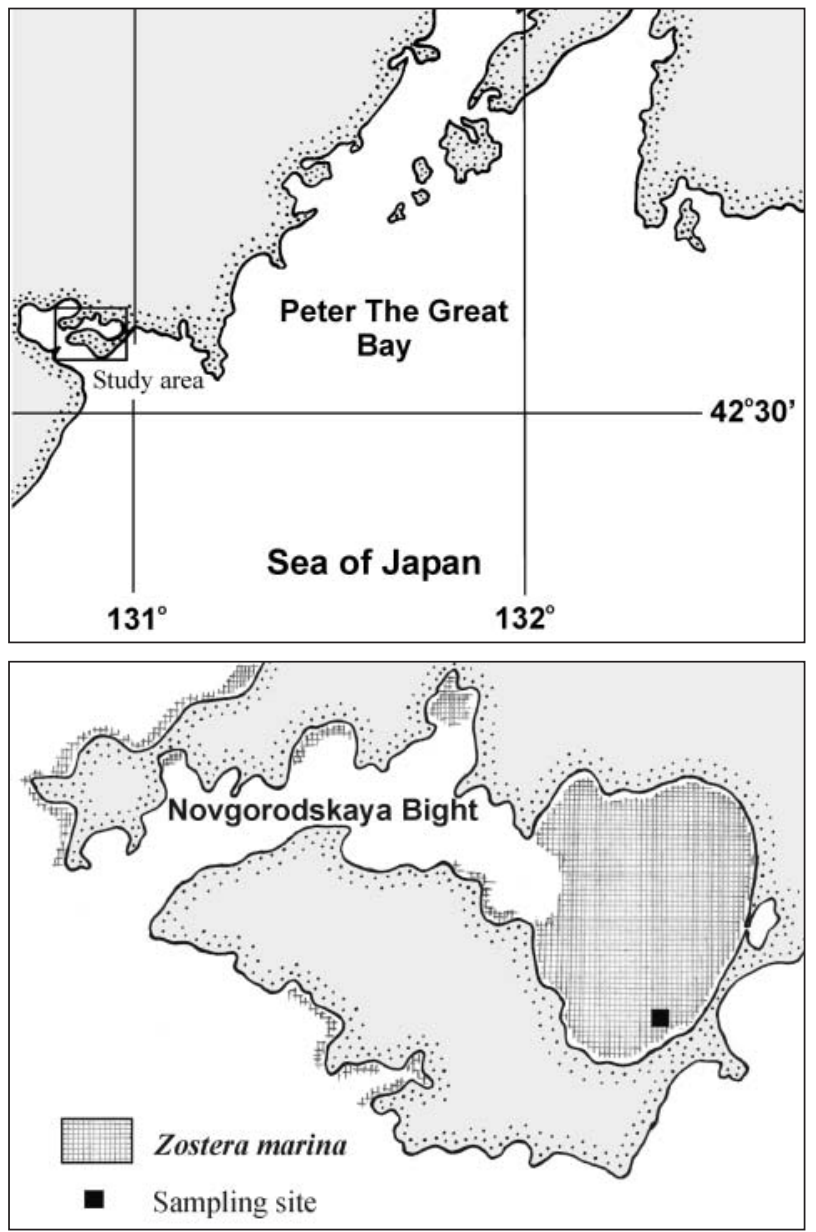

Fig. 1. Location of Zostera marina community and position of sampling site in the Novgorodskaya Bight (Possyet Bay, Sea of Japan)

Table 1. Characteristics of dominant invertebrate species in Zostera marina community (based on data from: Vyshkvartzev \& Peshekhodko 1982, Lebedev \& Vyshkvartzev 1988, 1990)

\begin{tabular}{|c|c|c|c|c|c|}
\hline Invertebrate species & Habitat & $\begin{array}{l}\text { Feeding } \\
\text { mode }\end{array}$ & $\begin{array}{l}\text { Maximal } \\
\text { iomass }\left(\mathrm{g} \mathrm{m}^{-2}\right)\end{array}$ & $\begin{array}{c}\% \text { of total } \\
\text { zoobenthos } \\
\text { biomass }\end{array}$ & $\begin{array}{c}\% \text { of total } \\
\text { community } \\
\text { biomass }\end{array}$ \\
\hline $\begin{array}{l}\text { Pillucina pisidium } \\
\text { (Dunker) }\end{array}$ & $\begin{array}{c}\text { Infauna } \\
\text { (in sediment) }\end{array}$ & $\begin{array}{l}\text { Filter feeding and } \\
\text { symbiotrophy }\end{array}$ & 75 & 1.3 & 0.1 \\
\hline $\begin{array}{l}\text { Littorina squalida } \\
\text { (Broderip et Sowerby) }\end{array}$ & $\begin{array}{c}\text { Epifauna of } \\
\text { eelgrass blades }\end{array}$ & Grazing & 52 & 2.8 & 0.3 \\
\hline $\begin{array}{l}\text { Batillaria cumingii } \\
\text { (Grosse) }\end{array}$ & $\begin{array}{l}\text { Epifauna } \\
\text { (on sediment) }\end{array}$ & $\begin{array}{l}\text { Surface-deposit } \\
\text { feeding }\end{array}$ & 234 & 3.6 & 0.4 \\
\hline $\begin{array}{l}\text { Homalopoma sangarense } \\
\text { (Schrenk) }\end{array}$ & $\begin{array}{c}\text { Epifauna of } \\
\text { eelgrass blades }\end{array}$ & Grazing & 97 & 4.8 & 0.5 \\
\hline $\begin{array}{l}\text { Ruditapes philippinarum } \\
\text { (Adams et Reeve) }\end{array}$ & $\begin{array}{c}\text { Infauna } \\
\text { (in sediment) }\end{array}$ & Filter feeding & 445 & 4.9 & 0.5 \\
\hline $\begin{array}{l}\text { Macoma incongrua } \\
\text { (Martens) }\end{array}$ & $\begin{array}{c}\text { Infauna } \\
\text { (in sediment) }\end{array}$ & $\begin{array}{l}\text { Surface-deposit feeding } \\
\text { and filter feeding }\end{array}$ & 354 & 72.9 & 7.9 \\
\hline
\end{tabular}


For isotope and lipid analyses, parts consisting mainly of muscle tissues were excised from the body of mollusks; the digestive organs and the gonads, which are rich in lipids, were discarded. For the bivalve Pillucina pisidium (in addition to the body tissues), the gills containing symbiotic bacteria (Rodionov \& Yushin 1991) were analysed separately.

Isotopic analysis. Since the sulfur SIRA requires a considerable amount of material, due to the relatively low content of organic sulfur (especially in plants), tissues of 10 to 100 individuals were pooled into 1 sample, depending on their size. All samples were washed with distilled water, dried at $60^{\circ} \mathrm{C}$ and ground to fine powder using an agate mortar and pestle.

For the carbon SIRA, subsamples of $1 \mathrm{mg}$ were combusted with $\mathrm{CuO}$ in vacuum-sealed Pyrex tubes in a muffle furnace at $590^{\circ} \mathrm{C}$ (Sofer 1980). Prior to combustion, subsamples of epiphytes, POM and sediments were treated with $1 \mathrm{~N} \mathrm{HCl}$ to remove carbonates, washed with distilled water and then dried again. After combustion, the resulting $\mathrm{CO}_{2}$ was purified by cryogenic distillation for analysis. The intercomparison material IAEA-C-6 (sucrose) was used as the running standard to control the entire procedure of sample preparation and carbon isotope analysis.

For sulfur isotope analysis, the remainder of each dried and ground sample was resuspended in deionized water $(1: 4, \mathrm{v} / \mathrm{v})$ and then centrifuged. The procedure was repeated 3 times in order to fully remove seawater sulfate from the samples (Peterson et al. 1986). The precipitate was dried at $60^{\circ} \mathrm{C}$ and ground again to fine powder. For converting organic sulfur to sulfate subsamples, 120 to $150 \mathrm{mg}$ of the animal tissues or $300 \mathrm{mg}$ of the plant tissues were mixed with $\mathrm{KNO}_{3}$ and combusted in vacuum-sealed Pyrex tubes (Dornblaser et al. 1994), to which $\mathrm{CaO}$ had been added to absorb excessive $\mathrm{CO}_{2}$ (B. Fry pers. comm.). After combustion, the contents of the tubes were dissolved by $1 \mathrm{~N} \mathrm{HCl}$, solutions were diluted with deionized water and filtrated, and then sulfur was precipitated with barium chloride to $\mathrm{BaSO}_{3}$. Pure $\mathrm{SO}_{2}$ was obtained after $\mathrm{BaSO}_{3}$ decomposition and cryogenic distillation. Samples of $1.5 \mathrm{mg}$ of IAEA-S-4 (elemental sulfur) served as the running standard to check the entire procedure of sample preparation and sulfur isotope analysis.

Isotope ratios were measured in $\mathrm{CO}_{2}$ and $\mathrm{SO}_{2}$ on a modified (for precise SIRA of gases) MI-1201V mass spectrometer in $\delta$ notation:

$$
\delta X(\%)=\left[\left(R_{\text {sample }} / R_{\text {standard }}\right)-1\right] \times 10^{3}
$$

where $X$ is ${ }^{13} \mathrm{C}$ or ${ }^{34} \mathrm{~S}$ and $R$ is ${ }^{13} \mathrm{C} /{ }^{12} \mathrm{C}$ or ${ }^{34} \mathrm{~S} /{ }^{32} \mathrm{~S}$. The $\delta$ values are expressed in parts per thousand relative to PDB (carbon) and CDT (sulfur) standards. Reference materials (NBS-19 and NBS-127) were used for calibration. Replicates using intercomparison materials
(IAEA-C-6 and IAEA-S-4) indicate overall analytical errors of $\pm 0.1 \%$ for $\delta^{13} \mathrm{C}$ and $\pm 0.2 \%$ for $\delta^{34} \mathrm{~S}$.

The contributions of 1 of 2 alternative sources to consumers were calculated by inserting $\delta^{13} \mathrm{C}$ or $\delta^{34} \mathrm{~S}$ values into the simple mixing equation (McConnaughey \& McRoy 1979):

$$
C_{(\mathrm{S} 1)}=\frac{\delta_{\mathrm{C}}-\delta_{\mathrm{S} 2}-F}{\delta_{\mathrm{S} 1}-\delta_{\mathrm{S} 2}} \times 100 \%
$$

where $C_{(\mathrm{S} 1)}$ is the contribution of Primary Source 1 to the consumer; $\delta_{\mathrm{C}}, \delta_{\mathrm{S} 1}$ and $\delta_{\mathrm{S} 2}$ are $\delta^{13} \mathrm{C}$ or $\delta^{34} \mathrm{~S}$ values of consumer, Primary Source 1, and Primary Source 2, correspondingly; $F$ is the trophic shift in consumer stable isotope ratios (+1\%o for carbon and $0 \%$ for sulfur).

Lipid extraction and analysis of fatty acids. The samples were transferred to a glass homogenizer and homogenized in a mixture of chloroform-methanol $(1: 1, v / v)$. Lipids were extracted according to Bligh \& Dyer (1959). Fatty acid methyl esters (FAME) were prepared by the consecutive treatment of the total lipids with $1 \%$ sodium methylate in methanol and $5 \%$ $\mathrm{HCl}$ in methanol according to Carreau \& Dubacq (1978) and purified by thin layer chromatography in benzene. A GC-9A gas chromatograph (Shimadzu, Kyoto, Japan) was used for analysis. Separation of FAME was performed on a fused quartz capillary column (30 m $\times 0.25 \mathrm{~mm}$ i.d.) coated with Supelcowax 10M (Supelco Co., Bellefonte, PA). The column and detector temperature was $210^{\circ} \mathrm{C}$, the injector temperature was $240^{\circ} \mathrm{C}$. Helium was used as a carrier gas, and the split ratio was 1:30. Individual peaks of FAME were identified by equivalent chain length measurements (Christie 1988) and by comparing retention times with those of the authentic standards of fatty acids. Chromatographic data were calculated with a Shimadzu Chromatopac C-R3A integrator.

Fatty acids were designed as the ratio of the number of carbon atoms to the number of double bonds. Double bond position (n) is numbered from the methyl end of the fatty acid.

Significant differences $(p<0.05)$ in fatty acid concentrations and SIRA data were tested between species or food sources using a 1-way ANOVA. All tests were performed using Statistica 4.0 statistical software.

\section{RESULTS}

\section{Carbon and sulfur stable isotopes in potential food sources}

The main sources of organic matter in the community exhibited a wide range $(14.2 \%$ ) of carbon isotope ratios (Table 2). The $\delta^{13} \mathrm{C}$ values varied from $-6.7 \%$ for 
green eelgrass leaves to $-20.9 \%$ for suspended POM. A much narrower range (within $5.5 \%$ ) was shown for sulfur isotope ratios of food sources. The maximum difference in $\delta^{34} \mathrm{~S}$ values was also found between eelgrass and suspended POM.

Live green leaves of Zostera marina, senescent brown leaves and fallen decomposing leaves showed very similar $\delta^{13} \mathrm{C}$ values (an average of $-7.0 \pm 0.5 \%$, $\mathrm{N}=6$ ), close to the maximum reported for this species (Hemminga \& Mateo 1996). Rhizomes of Z. marina were ${ }^{13} \mathrm{C}$-depleted in comparison to leaves; the average $\delta^{13} \mathrm{C}$ value of rhizomes was $1.9 \%$ less than that of leaves. The eelgrass leaves and rhizomes were substantially depleted in ${ }^{34} \mathrm{~S}$ relative to seawater sulfate, and showed $\delta^{34} \mathrm{~S}$ values from +8.9 to $+11.3 \%$. There was no significant difference in the sulfur isotopic composition between leaves and rhizomes (Table 2). Such depletion is common in higher marine plants rooted in reduced sediment (Trust \& Fry 1992); however, $Z$. marina from Novgorodskaya Bight had relatively high $\delta^{34} \mathrm{~S}$ values in comparison with the -0.4 to $+10 \%$ range known for this species from other marine basins (Mekhtieva et al. 1976, Peterson et al. 1986).

The structure of the epiphytic community of eelgrass blades in Novgorodskaya Bight is characteristic of seagrass meadows of the northwestern Sea of Japan, where they usually consist of the diatom Cocconeis scutellum, the small crustose coralline alga Pneophyllum lejolisii, fungi and bacteria (Kharlamenko \& Lysenko 1991b). Epiphytic algae were ${ }^{13} \mathrm{C}$-depleted compared to the eelgrass blades on which they grew; $\delta^{13} \mathrm{C}$ values were on average $6.5 \%$ lower than those for $Z$. marina blades and showed intermediate values (mean $=-13.5 \%$ o) between those of $Z$. marina and POM (Table 2). We were not able to measure sulfur isotopic composition of epiphytes because of the small amount of material in the samples. The $\delta^{34} \mathrm{~S}$ value for epiphytic algae in subtidal environments, such as the studied seagrass meadow, is expected to be close to that of seawater sulfate-about $+20.3 \%$ o (Nriagu et al. 1991), as is the case of Thalassia testudinum epiphytes (Fry et al. 1987) and many other marine algae (Trust \& Fry 1992); however, for epiphytes of saltmarsh grasses a very low $(-0.4 \%$ ) value has been reported (Currin et al. 1995).

The $\delta^{13} \mathrm{C}$ values (mean $=-20.9 \%$ ) of suspended POM (mainly zooplankton) were similar to that of phytoplankton (mainly diatoms
Chaetoceros spp.) collected $6 \mathrm{~km}$ apart from the seagrass meadow $\left(-20.7 \%\right.$ o). These $\delta^{13} \mathrm{C}$ values were in the typical range of marine temperate plankton (Gearing et al. 1984). The average $\delta^{34} \mathrm{~S}$ value $(+14.5 \%$ o) of suspended POM was lower than the +18.9 to $+21.0 \%$ range reported for plankton of near-shore waters of the Sea of Japan (Kiyashko et al. 1998). Visible absence of eelgrass detritus in these POM samples and their extremely low $\delta^{13} \mathrm{C}$ values compared to those of Zostera marina suggest that POM $\delta^{34} \mathrm{~S}$ values represent mainly the isotopic composition of copepods, which markedly dominated the structure of the seston in the $Z$. marina community during the sampling period. We suspect that the lower $\delta^{34} \mathrm{~S}$ values of suspended POM in the shallow waters of Novgorodskaya Bight are related to contamination of net tow samples by particles of resuspended sedimentary sulfide, as in the case of low $\delta^{34} \mathrm{~S}$ values of plankton samples from other muddy estuaries (Chanton \& Lewis 1999), and do not correctly reflect the isotopic composition of plankton organic sulfur, which should be close to that of seawater sulfate (Peterson et al. 1986, Kiyashko et al. 1998).

Benthic POM was substantially ${ }^{13} \mathrm{C}$-enriched in comparison to suspended POM, and showed a $\delta^{13} \mathrm{C}$ value $(-15.5 \%)$ very close to that of sedimentary organic matter (SOM) (Table 2). Eelgrass meadow SOM had a higher $\delta^{13} \mathrm{C}$ value $(-15.2 \%)$ than the values reported earlier (-18.1 to $-21.3 \%$ o) for sediments from the open, vegetation-free part of Novgorodskaya Bight (Zhakin \& Kiyashko 1991). This indicates that ${ }^{13} \mathrm{C}$-enriched detritus of Zostera marina or epiphytes make a substantial contribution to SOM in this ecosystem.
Table 2. Carbon and sulfur stable isotope ratios for potential food sources in the Zostera marina community of Novgorodskaya Bight, the Sea of Japan. Mean values marked by the same letter are not significantly different ( $p>0.05)$; unmarked mean values are significantly different (1-way ANOVA Tukey HSD-test, $\mathrm{p}<0.05)$. POM: particulate organic matter

\begin{tabular}{|lcccc|}
\hline Source & $\begin{array}{c}\delta^{13} \mathrm{C} \% \\
\text { Mean } \pm \mathrm{SD}\end{array}$ & $\mathrm{N}$ & $\begin{array}{r}\delta^{34} \mathrm{~S} \% \\
\text { Mean } \pm \mathrm{SD}\end{array}$ & $\mathrm{N}$ \\
\hline Eelgrass Zostera marina & & & & \\
$\quad$ Green leaves & $-6.7 \pm 0.1$ & 4 & $10.0^{\mathrm{a}} \pm 1.0$ & 4 \\
$\quad$ Senescent brown leaves & -7.9 & & & \\
Fallen decomposing leaves & -6.9 & & & \\
Rhizomes & $-8.9 \pm 0.1$ & 2 & $9.1^{\mathrm{a}} \pm 0.2$ & 2 \\
Epiphytic algae & $-13.5 \pm 0.3$ & 2 & & \\
(diatoms + Pneophyllum lejolisii) & & & & \\
Phytoplankton ${ }^{1}$ (mainly Chaetoceros spp.) & -20.7 & & & \\
Suspended POM (zooplankton) & $-20.9 \pm 0.3$ & 3 & $14.5 \pm 0.2$ & 2 \\
Benthic POM & -15.5 & & & \\
Sedimentary organic matter & -15.2 & & & \\
& & & & \\
${ }^{1}$ Net tow sample collected outside seagrass meadow & & & \\
\hline
\end{tabular}




\section{Fatty acids in potential food sources}

The major fatty acids of Zostera marina were 18:2(n-6), 18:3(n-3) and 16:0 (Table 3). These acids comprised $82.4 \%$ of the total fatty acids in live blades and $72.6 \%$ in rhizomes. Maximum concentrations of 18:3(n-3) occurred in the blades (mean $=41.3 \%$ ), and $18: 2(n-6)$ was the major fatty acid in the rhizomes $($ mean $=39.0 \%)$. The 18:2(n-6) and 18:3(n-3) acids are usually observed at high levels in seagrass blades (Nichols et al. 1982, Khotimchenko 1993), and the content of these acids in degraded seagrasses is usually markedly decreased (Tenore et al. 1984).

Decomposing leaves of Zostera marina lost a large portion of 18:2(n-6) and 18:3(n-3). The total content of 18:2(n-6) and 18:3(n-3) in degraded blades was diminished by a factor of 10.4 . The fatty acids $18: 2(n-6)$ and 18:3(n-3) made up $3.9 \%$ and $2.1 \%$, respectively, of the total fatty acids in lipids of $Z$. marina detritus (Table 3 ).

The major fatty acids in the total epiphyte samples were 14:0, 16:0, 16:1(n-7), 18:1(n-9) and 20:5(n-3). Their total content was $65.8 \%$. The predominance of diatom fatty acids has been reported for the epiphytic community of the seagrass Posidonia australis (Nichols et al. 1985).

In lipids of the suspended POM, the dominant fatty acids were 16:0,18:0, 20:5(n-3) and 22:6(n-3). The sum of these acids comprised $67.2 \%$ of the total fatty acids of suspended POM. The fatty acid composition of suspended POM was typical for marine POM in the period of abundant development of zooplankton, with a characteristic high content of 22:6(n-3) (Sargent \& Whittle 1981).

\section{Stable isotope ratios in dominant animals}

The composite samples of mollusks exhibited very low intraspecific variations of stable isotope ratios which commonly did not exceed $1 \%$ (Table 4 ); this was evidently a result of pooling more than 10 individuals in each sample. A wide range of interspecific differences (maximal difference $=16.4 \%$ ) was found in $\delta^{13} \mathrm{C}$ for mollusks. Nevertheless, the average $\delta^{13} \mathrm{C}$ values of 4 out of 6 species of animals were narrowly clustered in the -9.1 to $-12.3 \%$ range. Among these, the grazing

Table 3. Fatty acid composition of potential food sources in the Zostera marina community of Novgorodskaya Bight, the Sea of Japan ( $\%$ of total fatty acids, mean $\pm \mathrm{SD}, \mathrm{N}=3$ ). Table contains only fatty acids with concentrations $>1 \%$ in 1 of the food sources. Mean values marked by the same letter are not significantly different $(p>0.05)$; unmarked mean values (except data for $Z$. marina detritus) are significantly different (1-way ANOVA Tukey HSD test, p $\leq 0.05$ ). POM: particulate organic matter; SOM: sedimentary organic matter

\begin{tabular}{|c|c|c|c|c|c|c|c|}
\hline Fatty acid & $\begin{array}{l}\text { Z. marina } \\
\text { green leaves }\end{array}$ & $\begin{array}{l}\text { Z. marina } \\
\text { detritus }\end{array}$ & $\begin{array}{l}\text { Z. marina } \\
\text { rhizomes }\end{array}$ & $\begin{array}{c}\text { Epiphytes of } \\
\text { Z. marina }\end{array}$ & $\begin{array}{c}\text { Suspended } \\
\text { POM }\end{array}$ & $\begin{array}{l}\text { Benthic } \\
\text { POM }\end{array}$ & SOM \\
\hline $14: 0$ & $0.4^{\mathrm{a}} \pm 0.0$ & 3.4 & $0.6^{\mathrm{a}} \pm 0.0$ & $5.6^{b} \pm 0.5$ & $3.4^{\mathrm{b}} \pm 0.4$ & $3.9^{b} \pm 0.5$ & $3.4^{\mathrm{b}} \pm 0.3$ \\
\hline $14: 1$ & $0.1^{\mathrm{a}} \pm 0.0$ & 0.4 & $0.3^{\mathrm{a}} \pm 0.0$ & $1.1^{\mathrm{b}} \pm 0.3$ & $0.2^{\mathrm{a}} \pm 0.2$ & $1.2^{\mathrm{b}} \pm 0.3$ & $0.7^{\mathrm{b}} \pm 0.1$ \\
\hline i15:0 & 0 & 1.4 & $0.1^{a} \pm 0.1$ & $0.3^{\mathrm{a}} \pm 0.1$ & $0.4^{a} \pm 0.1$ & $1.0 \pm 0.1$ & $1.6 \pm 0.3$ \\
\hline ai15:0 & 0 & 0.7 & $0.2^{\mathrm{a}} \pm 0.0$ & $0.4^{\mathrm{ab}} \pm 0.2$ & $0.2^{\mathrm{ab}} \pm 0.1$ & $1.1^{\mathrm{b}} \pm 0.4$ & $2.8 \pm 0.8$ \\
\hline $15: 0$ & $0.2^{\mathrm{a}} \pm 0.0$ & 1.3 & $0.6^{\mathrm{ab}} \pm 0.1$ & $1.0^{\mathrm{bc}} \pm 0.3$ & $0.8^{\mathrm{b}} \pm 0.1$ & $1.3^{\mathrm{cd}} \pm 0.2$ & $1.7^{\mathrm{d}} \pm 0.1$ \\
\hline $16: 0$ & $19.9^{\mathrm{ab}} \pm 0.4$ & 20.6 & $19.5^{\mathrm{ab}} \pm 1$ & $23.8^{\mathrm{b}} \pm 2.9$ & $22.4^{\mathrm{ab}} \pm 1.1$ & $16.6^{\mathrm{a}} \pm 2.0$ & $16.7^{\mathrm{a}} \pm 1.7$ \\
\hline $16: 1(n-9)$ & $0.5 \pm 0.0$ & 0.0 & $2.0^{\mathrm{a}} \pm 0.1$ & 0 & $1.7^{\mathrm{a}} \pm 1.1$ & 0 & 0 \\
\hline $16: 1(n-7)$ & $0.8^{\mathrm{a}} \pm 0.1$ & 5.1 & 0 & $18.2^{\mathrm{b}} \pm 1.8$ & $2.1^{\mathrm{a}} \pm 0.4$ & $12 \pm 1.4$ & $15.8^{\mathrm{b}} \pm 1.7$ \\
\hline ai17:0 & 0 & 0.4 & $0.1^{\mathrm{a}} \pm 0.0$ & $0.4^{\mathrm{b}} \pm 0.0$ & $0.2^{\mathrm{a}} \pm 0.1$ & $0.5^{\mathrm{b}} \pm 0.1$ & $1.1 \pm 0.2$ \\
\hline $17: 0$ & $0.2^{\mathrm{a}} \pm 0.0$ & 0.7 & $0.7^{\mathrm{ab}} \pm 0.1$ & $0.4^{a} \pm 0.1$ & $0.8^{\mathrm{b}} \pm 0.4$ & $0.6^{\mathrm{ab}} \pm 0.2$ & $1.0^{\mathrm{b}} \pm 0.0$ \\
\hline $17: 1(n-9)$ & $0.1^{\mathrm{a}} \pm 0.0$ & 0.7 & $0.2^{\mathrm{a}} \pm 0.0$ & $1.5^{\mathrm{b}} \pm 0.2$ & $0.3^{\mathrm{a}} \pm 0.2$ & $1.9^{\mathrm{b}} \pm 0.5$ & $1.9^{\mathrm{b}} \pm 0.2$ \\
\hline $16: 3(n-3)$ & $3.5 \pm 0.5$ & 1.0 & $\begin{array}{c}0.2+0.0 \\
0\end{array}$ & $0.2^{\mathrm{a}} \pm 0.1$ & $0.2^{\mathrm{a}} \pm 0.1$ & $0.5^{\mathrm{ab}} \pm 0.2$ & $0.9^{\mathrm{b}} \pm 0.1$ \\
\hline $\begin{array}{l}18: 0(11-0) \\
18: 0\end{array}$ & $1.5^{\mathrm{a}} \pm 0.2$ & $\begin{array}{l}1.0 \\
6.9\end{array}$ & $2.2^{\mathrm{ab}} \pm 0.4$ & $3.8^{\mathrm{bc}} \pm 1.0$ & $5.2^{\mathrm{c}} \pm 0.4$ & $3.8^{\mathrm{bc}} \pm 0.1$ & $3.2^{\mathrm{abc}} \pm 0.6$ \\
\hline $18: 1(n-9)$ & $1.5^{\mathrm{a}} \pm 1.0$ & 12.9 & $3.2^{\mathrm{ab}} \pm 0.4$ & $10.5^{\mathrm{c}} \pm 1.1$ & $2.5^{\mathrm{ab}} \pm 0.8$ & $7.2^{\mathrm{bc}} \pm 2.9$ & $5.9^{\mathrm{b}} \pm 1.4$ \\
\hline $18: 1(n-7)$ & $0.5^{\mathrm{a}} \pm 0.2$ & 4.1 & $1.5^{\mathrm{ab}} \pm 0.4$ & $2.4^{\mathrm{b}} \pm 0.5$ & $1.9^{\mathrm{ab}} \pm 0.1$ & $3.9^{\mathrm{b}} \pm 1.2$ & $6.4 \pm 0.8$ \\
\hline $18: 2(n-6)$ & $21.2 \pm 0.2$ & 3.9 & $39.0 \pm 1.3$ & $3.2^{\mathrm{a}} \pm 0.1$ & $1.5^{\mathrm{a}} \pm 0.2$ & $3.7^{\mathrm{a}} \pm 1.7$ & $3.5^{\mathrm{a}} \pm 0.8$ \\
\hline $18: 3(n-3)$ & $41.3 \pm 3.7$ & 2.1 & $14.1 \pm 1.1$ & $0.9^{\mathrm{a}} \pm 0.3$ & $3.6^{\mathrm{a}} \pm 0.7$ & $1.3^{\mathrm{a}} \pm 0.3$ & $2.0^{\mathrm{a}} \pm 0.6$ \\
\hline $18: 4(n-4)$ & 0 & 0.1 & 0 & $0.6^{a} \pm 0.2$ & $4.4 \pm 0.9$ & $0.9^{a} \pm 0.4$ & $0.7^{a} \pm 0.1$ \\
\hline $20: 0$ & $0.7^{\mathrm{ab}} \pm 0.0$ & 0.8 & $1.2^{\mathrm{a}} \pm 0.2$ & $1.0^{\mathrm{a}} \pm 0.1$ & $0.1^{\mathrm{b}} \pm 0.1$ & $0.9^{\mathrm{a}} \pm 0.3$ & $1.2^{\mathrm{a}} \pm 0.7$ \\
\hline $20: 4(n-6)$ & 0 & 0.7 & 0 & $1.3^{\mathrm{a}} \pm 0.2$ & $0.5^{\mathrm{a}} \pm 0.1$ & $1.3^{\mathrm{a}} \pm 0.5$ & $3.1^{\mathrm{a}} \pm 0.8$ \\
\hline $20: 4(n-3)$ & 0 & 0.3 & 0 & $0.3^{a} \pm 0.1$ & $0.5^{\mathrm{a}} \pm 0.1$ & $0.4^{\mathrm{a}} \pm 0.7$ & $0.1^{a} \pm 0.1$ \\
\hline $20: 5(n-3)$ & $0.3 \pm 0.0$ & 1.3 & 0 & $7.7^{\mathrm{a}} \pm 2.0$ & $18.6 \pm 2.4$ & $5.8^{a} \pm 2.0$ & $4.9^{\mathrm{a}} \pm 1.7$ \\
\hline $22: 0$ & $1.9^{\mathrm{a}} \pm 0.1$ & 1.4 & $2.9^{a} \pm 0.2$ & $0.5^{\mathrm{a}} \pm 0.1$ & $0.2^{\mathrm{a}} \pm 0.2$ & $0.9^{a} \pm 0.8$ & $1.6^{a} \pm 0.8$ \\
\hline $22: 2(n-6)$ & $0.4^{\mathrm{a}} \pm 0.7$ & 0.7 & 0 & 0 & 0 & $2.3^{a} \pm 3.7$ & 0 \\
\hline $24: 0$ & $0.7^{\mathrm{a}} \pm 0.1$ & 1.0 & $3.3 \pm 0.4$ & $0.4^{\mathrm{a}} \pm 0.4$ & 0 & $0.3^{\mathrm{a}} \pm 0.3$ & $1.1^{\mathrm{a}} \pm 0.6$ \\
\hline $22: 6(n-3)$ & 0 & 3.3 & $0.7^{a} \pm 0.9$ & $0.8^{\mathrm{a}} \pm 0.2$ & $21.0 \pm 1.5$ & $5.2^{\mathrm{a}} \pm 6.8$ & $1.1^{\mathrm{a}} \pm 0.2$ \\
\hline
\end{tabular}


Table 4. Carbon and sulfur stable isotope ratios of consumer organisms in the Zostera marina community of Novgorodskaya Bight, the Sea of Japan. Mean values marked by the same letter are not significantly different ( $\mathrm{p}>0.05)$; unmarked mean values are significantly different (1-way ANOVA Tukey HSD test, $\mathrm{p} \leq 0.01$ )

\begin{tabular}{|c|c|c|c|c|c|c|}
\hline \multirow[t]{2}{*}{ Species } & \multicolumn{3}{|c|}{$\delta^{13} \mathrm{C}(\%)$} & \multicolumn{3}{|c|}{$\delta^{34} \mathrm{~S}(\% \mathrm{o})$} \\
\hline & Mean \pm SD & Range & $\mathrm{N}$ & Mean \pm SD & Range & $\mathrm{N}$ \\
\hline \multicolumn{7}{|l|}{ Pillucina pisidium } \\
\hline Body & $-26.2 \pm 0.3$ & -26.4 to -25.9 & 3 & $-16.0 \pm 1.0$ & -16.8 to -15.0 & 3 \\
\hline Gills & $-27.8 \pm 0.1$ & -27.9 to -27.7 & 3 & $-0.2^{1}$ & & 1 \\
\hline Littorina squalida & $-9.8^{\mathrm{a}} \pm 0.9$ & -10.9 to -9.1 & 4 & $14.1 \pm 0.1$ & 14.0 to 14.2 & 3 \\
\hline Batillaria cumingii & $-12.0^{\mathrm{b}} \pm 0.3$ & -12.3 to -11.7 & 3 & $7.6 \pm 0.5$ & 7.1 to 8.1 & 3 \\
\hline Homalopoma sangarense & $-10.0^{\mathrm{a}} \pm 0.4$ & -10.3 to -10.5 & 3 & $12.0^{\mathrm{c}} \pm 0.4$ & 11.5 to 12.3 & 3 \\
\hline Ruditapes philippinarum & $-19.4 \pm 0.2$ & -19.6 to -19.3 & 3 & $12.2^{\mathrm{c}} \pm 0.3$ & 12.0 to 12.5 & 3 \\
\hline Macoma incongrua & $-11.0^{\mathrm{ab}} \pm 0.3$ & -11.3 to -10.7 & 3 & $-3.8 \pm 0.2$ & -3.9 to -3.5 & 3 \\
\hline
\end{tabular}

gastropods Littorina squalida (mean $\delta^{13} \mathrm{C}=-9.8 \%$ ) and Homalopoma sangarense (mean $\delta^{13} \mathrm{C}=-10.0 \%$ ) had the highest and nearly identical values of $\delta^{13} \mathrm{C}$. Also, no significant difference was found between $\delta^{13} \mathrm{C}$ values of the deposit-feeding bivalve Macoma incongrua and grazers (Table 4). Another surfacedeposit feeder, the gastropod Batillaria cumingii, showed slightly lower $\delta^{13} \mathrm{C}$ values (mean $=-12 \%$ ) than those of grazers.

The filter feeder Ruditapes philippinarum was much more ${ }^{13} \mathrm{C}$-depleted (mean $\delta^{13} \mathrm{C}=-19.4 \%$ ) than grazers and deposit feeders. However, another filter-feeding bivalve, Pillucina pisidium, was an extremely ${ }^{13} \mathrm{C}$ depleted component of the studied community. The $\delta^{13} \mathrm{C}$ values of $P$. pisidium muscle tissues ( -26.4 to $-25.9 \%$ ) were at least $5 \%$ o lower than those of suspended POM, which was the most ${ }^{13} \mathrm{C}$-depleted food source in the community (Tables $2 \& 4$ ). Gills of $P$. pisidium, which contained dense populations of chemoautotrophic bacteria, were significantly more depleted in ${ }^{13} \mathrm{C}$ (on average $1.6 \%$ less) than muscle tissues (Table 4).

The $\delta^{34}$ S range for consumers (about 30\%) was much greater than that expected for producers. Among consumers, the interspecific differences in $\delta^{34} \mathrm{~S}$ values were considerably greater than the differences inferred from the carbon isotope ratios. Most species, with the exception of Ruditapes philippinarum and Homalopoma sangarense, significantly differ in their $\delta^{34} \mathrm{~S}$ values (Table 4 ). The grazing periwinkle Littorina squalida was most ${ }^{34} \mathrm{~S}$-enriched (mean $\delta^{34} \mathrm{~S}=+14.1 \%$ ) among consumers. Slightly lower $\delta^{34} \mathrm{~S}$ values (about $+12 \%$ ) were shown for another grazer ( $H$. sangarense) and the filter feeder $R$. philippinarum. The deposit feeder Macoma incongrua (mean $\delta^{34} \mathrm{~S}=-3.8 \%$ ) and particularly the symbiont-bearing bivalve Pillucina pisidium (mean $\delta^{34} \mathrm{~S}=-16.0 \%$ ) were extremely depleted in ${ }^{34} \mathrm{~S}$. Intermediate $\delta^{34} \mathrm{~S}$ values $(+7.6 \%$ ) were found for another surface-deposit feeder (Batillaria cumingii).

\section{Fatty acid composition of dominant animal species}

In decreasing order of importance, 16:0 and 18:0 were the dominant saturated fatty acids of all macroconsumers studied (Table 5). A high concentration of 14:0 was found only in Pillucina pisidium. The major monoenic acids (content $>5 \%$ ) were 16:1(n-7) in $P$. pisidium, 18:1(n-9) in Macoma incongrua and Homalopoma sangarense, 18:1(n-7) in $H$. sangarense and $P$. pisidium, and 20:1(n-11) in M. incongrua and Littorina squalida. Polyenoic acids with a content of $>5 \%$ were 18:2(n-6) in Batillaria cumingii, 20:4(n-6) in all gastropods and in the bivalve $M$. incongrua, 20:5(n-3) in all mollusks, except $P$. pisidium, and 22:6(n-3) in $M$. incongrua and particularly Ruditapes philippinarum. We note that non-methylene-interrupted (NMI) acids were present in all species studied (Table 5).

\section{Isotopic and lipid markers in the community food web}

The stable isotopic composition of consumers and the main primary producers were superimposed on the $\delta^{34} \mathrm{~S}$ versus $\delta^{13} \mathrm{C}$ diagram (Fig. 2). Only 2 species of animals fell within the area, determined by $\delta^{13} \mathrm{C}$ and $\delta^{34} \mathrm{~S}$ values of the main primary producers; the eelgrass blade epifaunal gastropods Littorina squalida and Homalopoma sangarence occupied an intermediate position between Zostera marina and epiphytes.

All bottom dwelling species differed in ${ }^{34} \mathrm{~S}$ and/or ${ }^{13} \mathrm{C}$ from the primary producers sampled. The $\delta^{13} \mathrm{C}$ values of the filter feeder Ruditapes philippinarum and the deposit feeders Batillaria cumingii and Macoma 
Table 5. Fatty acid composition of consumers in the Zostera marina community of Novgorodskaya Bight, the Sea of Japan (mean $\pm \mathrm{SD}, \mathrm{N}=3, \%$ of total fatty acids). Table contains only fatty acids with concentrations $>1 \%$ in 1 of the consumers. Mean values marked by the same letter are not significantly different $(p>0.05)$; not marked mean values are significantly different $(1$-way ANOVA Tukey HSD test, $\mathrm{p} \leq 0.05)$. Pa: phytanic acid

\begin{tabular}{|c|c|c|c|c|c|c|c|}
\hline Fatty acid & $\begin{array}{l}\text { Pillucina } \\
\text { pisidium }\end{array}$ & $\begin{array}{c}\text { Pillucina } \\
\text { pisidium (gills) }\end{array}$ & $\begin{array}{l}\text { Littorina } \\
\text { squalida }\end{array}$ & $\begin{array}{l}\text { Batillaria } \\
\text { cumingii }\end{array}$ & $\begin{array}{c}\text { Homalopoma } \\
\text { sangarense }\end{array}$ & $\begin{array}{c}\text { Ruditapes } \\
\text { philippinarum }\end{array}$ & $\begin{array}{c}\text { Macoma } \\
\text { incongrua }\end{array}$ \\
\hline $14: 0$ & $8.1 \pm 1.3$ & $1.8^{\mathrm{ab}} \pm 0.3$ & $2.9^{\mathrm{a}} \pm 0.2$ & $1.6^{\mathrm{ab}} \pm 0.2$ & $2.5^{\mathrm{ab}} \pm 1.2$ & $1.2^{\mathrm{b}} \pm 0.3$ & $1.3^{\mathrm{ab}} \pm 0.4$ \\
\hline $15: 0$ & $0.5^{\mathrm{a}} \pm 0.0$ & $0.7^{a} \pm 0.2$ & $0.4^{\mathrm{a}} \pm 0.1$ & $0.9^{\mathrm{a}} \pm 0.1$ & $0.9^{\mathrm{a}} \pm 0.3$ & $0.6^{\mathrm{a}} \pm 0.0$ & $1.6 \pm 0.2$ \\
\hline $16: 0$ & $15.0^{\mathrm{ab}} \pm 2.4$ & $10.5^{\mathrm{bc}} \pm 0.8$ & $8.5^{\mathrm{C}} \pm 0.4$ & $7.3^{\mathrm{C}} \pm 0.8$ & $16.7^{\mathrm{a}} \pm 3.4$ & $14.8^{\mathrm{ab}} \pm 0.7$ & $9.4^{\mathrm{C}} \pm 1.6$ \\
\hline 16:1(n-9) & 0 & 0 & $0.5^{\mathrm{a}} \pm 0.8$ & $0.6^{\mathrm{a}} \pm 1.1$ & $1.2^{\mathrm{a}} \pm 2.2$ & $0.3^{\mathrm{a}} \pm 0.5$ & $0.4^{\mathrm{a}} \pm 0.7$ \\
\hline $16: 1(n-7)$ & $10.1 \pm 1.0$ & $19.6 \pm 0.7$ & $2.1^{\mathrm{a}} \pm 0.7$ & $2.5^{\mathrm{a}} \pm 0.7$ & $4.1^{\mathrm{a}} \pm 0.9$ & $2.8^{\mathrm{a}} \pm 1.1$ & $3.3^{\mathrm{a}} \pm 1.4$ \\
\hline i17:0 & $0.4^{\mathrm{a}} \pm 0.0$ & $0.3^{\mathrm{a}} \pm 0.1$ & $0.4^{\mathrm{a}} \pm 0.2$ & $1.0^{\mathrm{b}} \pm 0.1$ & $0.6^{\mathrm{a}} \pm 0.1$ & $1.3^{\mathrm{b}} \pm 0.1$ & $1.3^{\mathrm{b}} \pm 0.2$ \\
\hline ai17:0 & $0.3^{\mathrm{ab}} \pm 0.0$ & $0.3^{\mathrm{a}} \pm 0.0$ & $0.2^{\mathrm{a}} \pm 0.0$ & $0.9^{b} \pm 0.1$ & $0.3^{\mathrm{a}} \pm 0.1$ & $1.7 \pm 0.1$ & $0.5^{\mathrm{ab}} \pm 0.0$ \\
\hline $16: 2+\mathrm{Pa}$ & $0.3^{\mathrm{a}} \pm 0.0$ & $0.4^{\mathrm{a}} \pm 0.0$ & $0.4^{\mathrm{a}} \pm 0.1$ & $1.1^{b} \pm 0.2$ & $0.2^{\mathrm{a}} \pm 0.1$ & $1.4^{\mathrm{b}} \pm 0.4$ & $0.4^{\mathrm{a}} \pm 0.0$ \\
\hline $17: 0$ & $0.7^{a} \pm 0.0$ & $1.0^{\mathrm{b}} \pm 0.1$ & $0.3^{\mathrm{c}} \pm 0.0$ & $1.4^{\mathrm{d}} \pm 0.1$ & $1.4^{\mathrm{d}} \pm 0.0$ & $1.3^{\mathrm{d}} \pm 0.0$ & $0.6^{\mathrm{a}} \pm 0.0$ \\
\hline $18: 0$ & $7.9^{a} \pm 0.8$ & $5.6^{b} \pm 0.3$ & $8.1^{a} \pm 0.9$ & $6.9^{\mathrm{ab}} \pm 0.6$ & $4.9^{\mathrm{ab}} \pm 1.0$ & $7.1^{\mathrm{ab}} \pm 0.4$ & $6.4^{\mathrm{ab}} \pm 1.2$ \\
\hline 18:1(n-9) & $1.7^{\mathrm{a}} \pm 0.1$ & $3.6^{\mathrm{ab}} \pm 0.6$ & $4.0^{\mathrm{ab}} \pm 0.8$ & $3.5^{\mathrm{ab}} \pm 0.4$ & $5.5^{\mathrm{b}} \pm 1.2$ & $3.2^{\mathrm{ab}} \pm 0.2$ & $9.2 \pm 0.9$ \\
\hline $18: 1(n-7)$ & $11.1^{\mathrm{a}} \pm 0.8$ & $15.9 \pm 0.6$ & $1.7^{\mathrm{b}} \pm 0.3$ & $1.7^{\mathrm{b}} \pm 0.1$ & $9.3^{\mathrm{a}} \pm 0.7$ & $2.3^{\mathrm{b}} \pm 0.5$ & $1.1^{\mathrm{b}} \pm 0.2$ \\
\hline $18: 2(n-6)$ & $1.5^{\mathrm{a}} \pm 0.1$ & $2.8^{\mathrm{ab}} \pm 0.5$ & $3.5^{\mathrm{abc}} \pm 1.1$ & $6.4^{\mathrm{c}} \pm 0.8$ & $4.1^{\mathrm{abc}} \pm 1.4$ & $0.8^{\mathrm{a}} \pm 0.3$ & $3.6^{\mathrm{ab}} \pm 2.6$ \\
\hline $19: 1$ & $0.4^{\mathrm{a}} \pm 0.3$ & $0.3^{\mathrm{a}} \pm 0.4$ & $1.2^{\mathrm{a}} \pm 2.1$ & $0.6^{\mathrm{a}} \pm 0.9$ & $0.4^{\mathrm{a}} \pm 0.7$ & $0.2^{\mathrm{a}} \pm 0.3$ & $0.6^{\mathrm{a}} \pm 0.8$ \\
\hline $18: 3(n-3)$ & $1.4^{\mathrm{a}} \pm 0.2$ & $1.3^{\mathrm{a}} \pm 0.1$ & $1.5^{\mathrm{a}} \pm 0.3$ & $1.2^{\mathrm{a}} \pm 0.3$ & $0.7^{\mathrm{a}} \pm 0.1$ & $0.8^{\mathrm{a}} \pm 0.2$ & $0.9^{\mathrm{a}} \pm 0.4$ \\
\hline $18: 4(n-3)$ & $0.2^{\mathrm{a}} \pm 0.0$ & $0.1^{\mathrm{a}} \pm 0.1$ & $0.3^{\mathrm{a}} \pm 0.0$ & $0.3^{\mathrm{a}} \pm 0.1$ & 0 & $0.7^{\mathrm{a}} \pm 0.2$ & $0.5^{\mathrm{a}} \pm 0.2$ \\
\hline $20: 0$ & $0.3^{\mathrm{a}} \pm 0.0$ & $0.2^{\mathrm{a}} \pm 0.0$ & $0.1^{\mathrm{a}} \pm 0.0$ & $0.2^{\mathrm{a}} \pm 0.0$ & $0.1^{\mathrm{a}} \pm 0.1$ & $0.3^{\mathrm{a}} \pm 0.2$ & $0.1^{\mathrm{a}} \pm 0.0$ \\
\hline 20:1(n-11) & $2.6^{\mathrm{a}} \pm 0.1$ & $1.4^{\mathrm{a}} \pm 0.6$ & $9.3^{\mathrm{b}} \pm 1.3$ & $4.7^{\mathrm{a}} \pm 0.5$ & $3.3^{\mathrm{a}} \pm 0.5$ & $4.0^{\mathrm{a}} \pm 0.3$ & $11.1^{\mathrm{b}} \pm 2.7$ \\
\hline $20: 1(n-9)$ & $1.7^{\mathrm{ab}} \pm 0.1$ & $1.1^{\mathrm{a}} \pm 0.1$ & $0.6^{\mathrm{c}} \pm 0.5$ & $0.4^{\mathrm{c}} \pm 0.1$ & 0 & $1.9^{\mathrm{b}} \pm 0.2$ & $0.6^{\mathrm{c}} \pm 0.5$ \\
\hline $20: 1(n-7)$ & $5.6 \pm 0.4$ & $4.1^{\mathrm{c}} \pm 0.2$ & $2.1^{\mathrm{a}} \pm 0.2$ & $1.2^{\mathrm{b}} \pm 0.1$ & $0.3^{\mathrm{b}} \pm 0.0$ & $1.9^{\mathrm{a}} \pm 0.1$ & $3.8^{\mathrm{c}} \pm 0.7$ \\
\hline 20:2nmi & $1.7^{\mathrm{a}} \pm 0.2$ & $0.8^{\mathrm{a}} \pm 0.1$ & $0.1^{\mathrm{a}} \pm 0.1$ & $0.3^{\mathrm{a}} \pm 0.0$ & 0 & $0.1^{\mathrm{a}} \pm 0.1$ & $0.2^{\mathrm{a}} \pm 0.1$ \\
\hline $20: 2(n-6)$ & $1.0^{\mathrm{a}} \pm 0.2$ & $0.7^{\mathrm{a}} \pm 0.1$ & $6.7^{\mathrm{b}} \pm 1.7$ & $4.4^{\mathrm{ab}} \pm 0.1$ & $1.6^{\mathrm{ab}} \pm 0.1$ & $2.5^{\mathrm{ab}} \pm 0.2$ & $1.5^{\mathrm{ab}} \pm 0.7$ \\
\hline $20: 4(n-6)$ & $3.9^{\mathrm{a}} \pm 0.4$ & $4.2^{\mathrm{a}} \pm 0.1$ & $12.3^{\mathrm{b}} \pm 2.3$ & $17.1 \pm 1.1$ & $13.2^{\mathrm{b}} \pm 1.9$ & $3.3^{\mathrm{a}} \pm 0.1$ & $6.4^{\mathrm{a}} \pm 1.4$ \\
\hline $20: 4(n-3)$ & $2.1^{\mathrm{a}} \pm 0.3$ & $1.5^{\mathrm{a}} \pm 0.1$ & $0.2^{\mathrm{b}} \pm 0.0$ & $0.2^{\mathrm{b}} \pm 0.1$ & 0 & $0.5^{\mathrm{b}} \pm 0.1$ & $0.2^{\mathrm{b}} \pm 0.2$ \\
\hline $20: 5(n-3)$ & $3.1^{\mathrm{a}} \pm 0.3$ & $2.3^{\mathrm{a}} \pm 0.2$ & $12.8 \pm 2.4$ & $6.6^{\mathrm{a}} \pm 0.9$ & $5.7^{\mathrm{a}} \pm 0.9$ & $7.1^{\mathrm{a}} \pm 1.2$ & $7.4^{a} \pm 3.5$ \\
\hline $22: 2 \Delta 7,13$ & $1.1^{\mathrm{a}} \pm 0.1$ & $1.3^{\mathrm{a}} \pm 0.2$ & $5.5^{\mathrm{b}} \pm 0.9$ & $4.0^{\mathrm{b}} \pm 0.4$ & $0.9^{\mathrm{a}} \pm 0.2$ & $2.2 \pm 0.2$ & $0.1^{\mathrm{a}} \pm 0.0$ \\
\hline $22: 2 \Delta 7,15$ & $4.2^{\mathrm{a}} \pm 0.1$ & $5.1^{\mathrm{a}} \pm 0.1$ & $3.1 \pm 0.5$ & $5.1^{\mathrm{a}} \pm 0.5$ & $6.0 \pm 1.0$ & $4.9^{\mathrm{a}} \pm 0.2$ & 0 \\
\hline $22: 4(n-6)$ & $0.4^{\mathrm{a}} \pm 0.4$ & $0.6^{\mathrm{a}} \pm 0.0$ & $0.7^{a} \pm 0.1$ & $2.3^{b} \pm 0.3$ & $1.9^{\mathrm{b}} \pm 0.4$ & $1.7^{b} \pm 0.3$ & $1.4^{\mathrm{b}} \pm 0.2$ \\
\hline $22: 5(n-3)$ & $0.3^{\mathrm{a}} \pm 0.0$ & $0.2^{\mathrm{a}} \pm 0.2$ & $2.7^{\mathrm{b}} \pm 0.4$ & $3.9^{b} \pm 0.6$ & $4.7 \pm 0.8$ & $2.7^{b} \pm 0.2$ & $2.7^{\mathrm{b}} \pm 1.0$ \\
\hline $22: 6(n-3)$ & $0.8^{\mathrm{a}} \pm 0.3$ & $0.7^{a} \pm 0.3$ & $0.7^{a} \pm 0.6$ & $1.8^{\mathrm{a}} \pm 0.5$ & $1.4^{\mathrm{a}} \pm 1.0$ & $16.4 \pm 0.7$ & $5.6^{a} \pm 0.5$ \\
\hline $24: 1$ & 0 & $1.4 \pm 1.2$ & 0 & 0 & 0 & 0 & 0 \\
\hline
\end{tabular}

incongrua corresponded to those of a mixture of phytoplankton and eelgrass in different proportions, but all

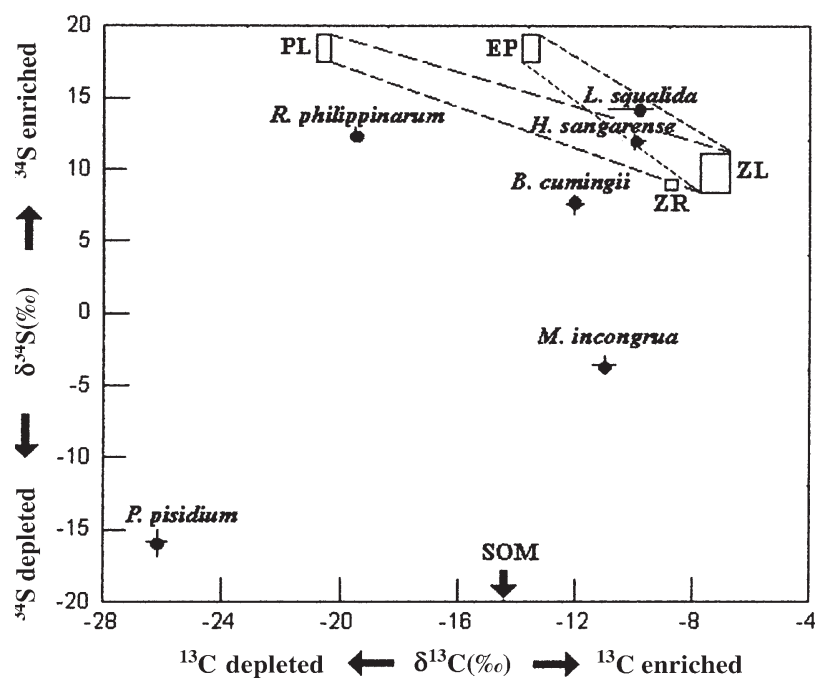

these mollusks were much more ${ }^{34} \mathrm{~S}$-depleted than would be expected from their feeding on such a mixture (Fig. 2). Consumption of other non-sampled food sources, such as ${ }^{34} \mathrm{~S}$-depleted benthic diatoms or bacteria, could be inferred for these animals from consideration of isotopic data only. The infaunal bivalve Pillucina pisidium, which bears chemoautotrophic bacterial symbionts, greatly differed in isotopic composition (both carbon and sulfur) from all photosynthetic producers in the community (Fig. 2).

Fig. 2. Plot of $\delta^{13} \mathrm{C}$ versus $\delta^{34} \mathrm{~S}$ values for consumers and food sources from the Zostera marina community of Novgorodskaya Bight, expressed as parts per thousand (\%). Mean value and range are shown for consumers. Food sources include: PL, phytoplankton; EP, epiphytes of eelgrass blades; ZL, Z. marina leaves; ZR, $Z$. marina rhizomes. The $\delta^{34}$ S values for PL and EP are based on literature values for marine algae. Broken lines outline the area of mixing of alternative food sources 
The fatty acids and fatty acid ratios used to define food sources in the Zostera marina community are shown in Table 6. Only insignificant amounts of the acids 18:2(n-3) and 18:3(n-3), which are characteristic of $Z$. marina blades, were found in all studied animals (Fig. 3A). Even in Littorina squalida and Homalopoma sangarence, which are the closest to $Z$. marina by isotopic markers, the levels of these fatty acids were low. No significant differences were observed in the amounts of these fatty acids between studied mollusks.

The diatoms should be characterized by a 16:1/16:0 ratio $\geq 1$ along with a high content of the acid 20:5(n-3). In all consumers, including the epifaunal gastropods of Zostera marina blades, the 16:1/16:0 ratio was much less than 1. An exception was found in the bivalve Pillucina pisidium; however, it had a low content of 20:5(n-3) (Fig. 3B).

A high concentration of $\mathrm{C}_{18}$ and $\mathrm{C}_{20}$ polyunsaturated fatty acids (PUFA) is typical of many macroalgae (Kayama et al. 1989). Among the animals from the Zostera marina community, high levels of $\mathrm{C}_{18}$ and $\mathrm{C}_{20}$ PUFA occurred only in gastropods, both grazers and deposit feeders. It should be pointed out that very high concentrations of 20:4(n-6) acid were detected in gastropods (Fig. 3C).

Among the studied consumers of the community, a high concentration of 22:6(n-3), specific to zooplankton, was observed only in the filter feeder Ruditapes philippinarum (Fig. 3D), which was also very similar to POM based on its isotopic composition (Fig. 2).
The tissues of the investigated consumers of the Zostera marina community contained an appreciable quantity of the acid 18:1(n-7), typical for bacteria. Very high concentrations of 18:1(n-7) occurred in both the muscle tissue and the bacteria-bearing gills of the bivalve Pillucina pisidium and in the muscle tissue of the grazing gastropod Homalopoma sangarence. P. pisidium significantly differed $(\mathrm{p}<0.01)$ from other mollusks by the highest 18:1(n-7)/18:1(n-9) ratio. Elevated levels of branched fatty acids, characteristic of bacteria inhabiting marine sediments, were found in the infaunal bivalves Ruditapes philippinarum and Macoma incongrua, as well as in the surface-depositfeeding gastropod Batillaria cumingii (Fig. 3E).

\section{DISCUSSION}

The structure of the eelgrass community in Novgorodskaya Bight is typical of many seagrass ecosystems. In such ecosystems, the organic matter of seagrasses dominated the primary producer biomass, while consumer biomass is dominated by bivalves and gastropods. Of the consumers, we consider those species of invertebrates which comprise the main part of community biomass. Unlike the traditional comparative analysis of representatives from different trophic groups, this approach has allowed a more adequate representation of the major fluxes to the upper trophic levels of the ecosystem.

Table 6. Fatty acids and fatty acid ratios that were used as markers for food sources in the Zostera marina ecosystem. Main sources are abundant groups with high levels of marker acids. Other important sources are less abundant groups or groups having species with high levels of marker fatty acids

\begin{tabular}{|c|c|c|c|c|}
\hline Fatty acid & Main sources & Other important sources & Ratio & Marker for: \\
\hline $16: 1(n-7)$ & Diatoms (1) & Bacteria (2) & $16: 1(n-7) / 16: 0$ & $\begin{array}{l}\text { Diatoms (1), } \\
\text { bacteria (4) }\end{array}$ \\
\hline iso17:0; anteiso17:0 & \multicolumn{4}{|l|}{ Bacteria (3) } \\
\hline $18: 1(n-7)$ & \multicolumn{2}{|l|}{ Bacteria (4) } & 18:1(n-7)/18:1(n-9) & Bacteria (10) \\
\hline $18: 2(n-6)$ & Z. marina (5) & Algae (6), fungi (7), protozoa (9) & $\begin{array}{l}18: 2(n-6)+18: 3(n-3) / \\
C_{20}+C_{22} \text { PUFAs }\end{array}$ & Z. marina (11) \\
\hline $18: 3(n-3)$ & \multirow[t]{3}{*}{ Z. marina (5) } & \multicolumn{3}{|l|}{ Fungi (7), algae (6) } \\
\hline $18: 4(n-3)$ & & \multicolumn{3}{|l|}{ Dinoflagellates (8), cryptomonads (8) } \\
\hline $20: 4(n-3)$ & & \multicolumn{3}{|l|}{ Fungi (7), protozoa (9), algae (6) } \\
\hline $20: 5(n-3)$ & $\begin{array}{l}\text { Diatoms (1), } \\
\text { Pneophylum lejolisii (5) }\end{array}$ & \multicolumn{3}{|l|}{ Algae (6) } \\
\hline $22: 6(n-3)$ & Zooplankton (5) & \multicolumn{3}{|l|}{$\begin{array}{l}\text { Protozoa (9), dinoflagellates (8), } \\
\text { cryptomonads (8) }\end{array}$} \\
\hline \multicolumn{5}{|c|}{$\begin{array}{l}\text { References: (1) Ackman et al. (1968), (2) Gillian \& Hogg (1984), (3) Findlay et al. (1990), (4) Volkman et al. (1980), (5) present } \\
\text { study, (6) Kayama et al. (1989), (7) Erwin (1973), (8) Sargent et al. (1987), (9) Zhukova \& Kharlamenko (1999), (10) Pond et al. } \\
\text { (1997), (11) Nichols et al. (1986) }\end{array}$} \\
\hline
\end{tabular}



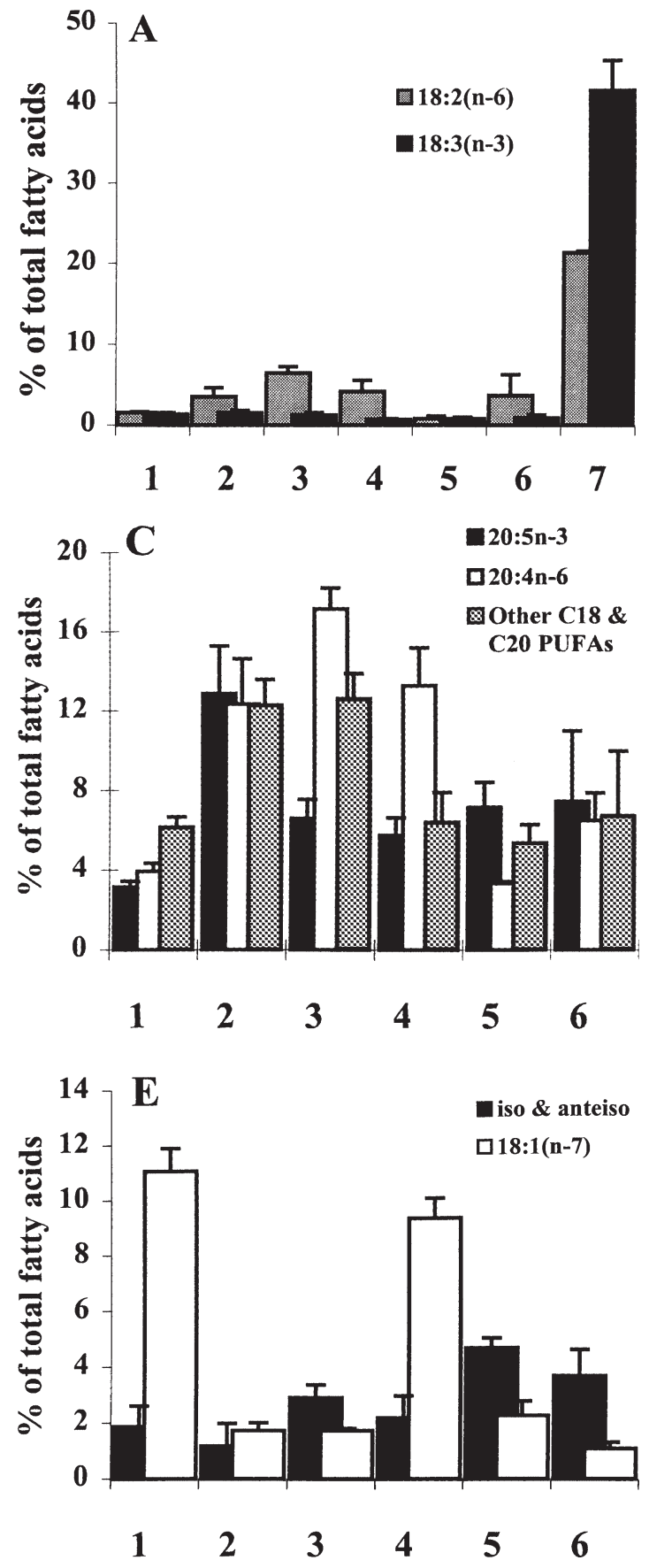

Of the dominant consumers in the Zostera marina community of Novgorodskaya Bight, the tiny bivalve Pillucina pisidium comprised $1.3 \%$ of total zoobenthos biomass. Similarly to other members of the family Lucinidae, this species can feed as a filter feeder and also has numerous chemoautotrophic bacterial endosymbionts inhabiting cells of its enlarged gills (Rodionov \& Yushin 1991).

Symbiont-free body tissues of Pillucina pisidium were dramatically depleted in heavy isotopes, both ${ }^{13} \mathrm{C}$
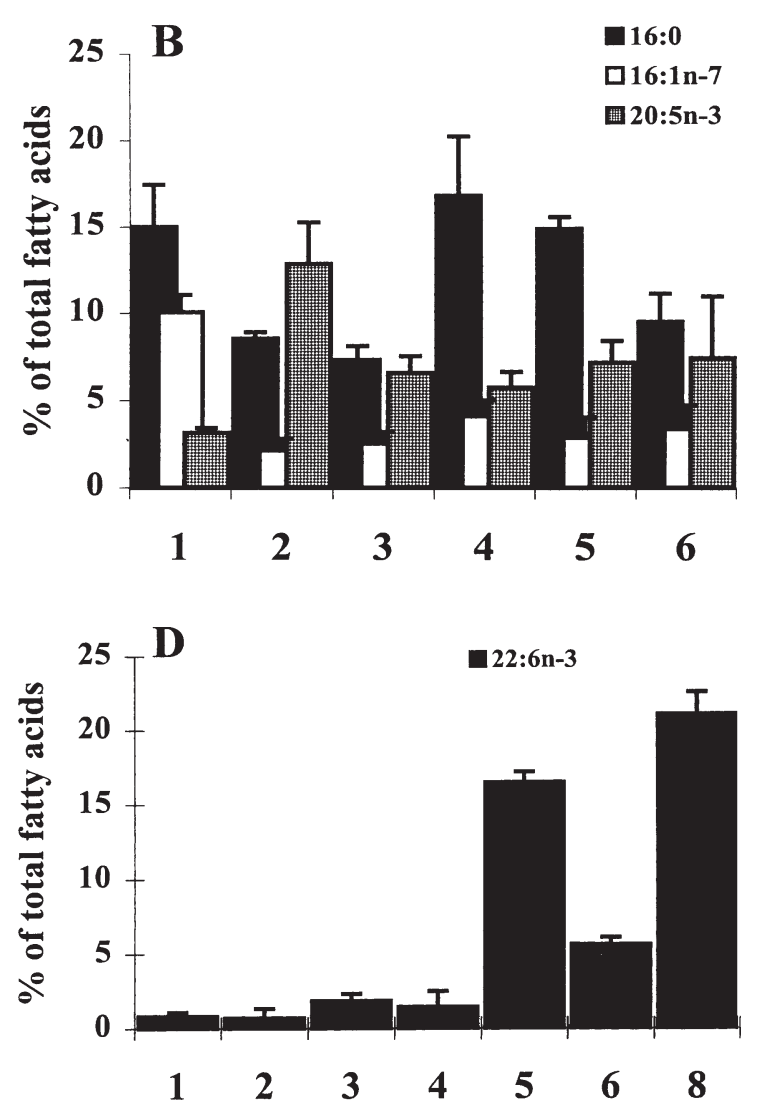

Fig. 3. Content of specific marker fatty acids in dominant animals and some food sources of the Zostera marina community: (A) for seagrass; (B) for diatoms; (C) for macroalgae; (D) for zooplankton; and (E) for bacteria. 1, Pillucina pisidium; 2, Littorina squalida; 3, Batillaria cumingii; 4, Homalopoma sangarense; 5, Ruditapes philippinarum; 6, Macoma incongrua; 7, Zostera marina; 8, zooplankton. Iso \& anteiso: sum of iso and anteiso fatty acids

and ${ }^{34} \mathrm{~S}$, compared to all sources of photosynthetically fixed carbon in the bight. The gills, containing symbionts, had significantly ( $p=0.01$ ) less ${ }^{13} \mathrm{C}$ than other body tissues (Table 4), evidently due to the presence of a huge amount of ${ }^{13} \mathrm{C}$-depleted bacteria. Sulfur-oxidizing chemoautotrophic bacteria discriminate heavy carbon isotopes to a greater degree than do marine photoautotrophs (Ruby et al. 1987), and very low $\delta^{13} \mathrm{C}$ values $(-34.0$ to $-31.7 \%$ ) were shown for sulfur-oxidizing bacteria isolated from symbiont-bearing bivalves (Cary et al. 1989, Conway et al. 1989).

Total sulfur content in the gill sample of Pillucina pisidium exceeded $15 \%$ of its dry weight due to the presence of elemental sulfur reserves in the cells of sulfur-oxidizing symbionts; therefore, $\delta^{34} \mathrm{~S}$ value of the gill sample $(+0.2 \%)$ reflects the isotope composition of elemental sulfur, rather than symbiont and host organic sulfur. Organic sulfur of symbiont-free tissues 
was greatly depleted in ${ }^{34} \mathrm{~S}$, as a result of a major contribution of reduced sulfur from interstitial water of the anaerobic sediment throughout symbiotrophic feeding upon sulfur-oxidizing bacteria.

Contribution of chemoautotrophs to Pillucina pisidium feeding was calculated, using $\delta^{13} \mathrm{C}$ values for symbiotic bacteria $($ mean $=-33 \%$ ) $($ Cary et al. 1989, Conway et al. 1989) and suspended POM $(-20.9 \%$ ) as endmembers in Eq. (2). This conservative estimate shows that at least $52 \%$ of host organic carbon was derived from symbionts.

The fatty acid composition of this mollusk is characterized by a high content of 18:1(n-7). The increased concentration of this acid has been reported for other symbiont-bearing mollusks (Conway \& McDowell Capuzzo 1991), as well as Pillucina pisidium from Vostok Bay in the Sea of Japan (Zhukova et al. 1992). Another distinctive feature of mollusks with bacterial symbionts, namely a very low level of (n-3) PUFAs, was detected in this animal. The sum of essential PUFAs [20:4(n-6), 20:5(n-3) and 22:6(n-3)] in the tissue of this mollusk was significantly lower $(p=0.05)$ than in any studied invertebrate from this ecosystem.

The gastropod Littorina squalida constitutes only $2.3 \%$ of total consumer biomass in the community studied. Epiphytic algae and Zostera marina are accessible primary producers for this grazing consumer. It has been demonstrated that some species of grazing gastropods actually feed on seagrasses, and sometimes they are the only consumers of seagrass among all animals studied in the ecosystem (Stephenson et al. 1986). L. squalida exhibited the highest $\delta^{13} \mathrm{C}$ and $\delta^{34} \mathrm{~S}$ values among consumers. On the dual isotope plot (Fig. 2), this mollusk occupies an intermediate position between $Z$. marina and epiphytic algae, suggesting a nearly equal consumption of organic matter from both sources; the contribution of eelgrass ranges from $41 \%$ (estimated from $\delta^{13} \mathrm{C}$ data) to $52 \%$ (estimated from $\delta^{34} \mathrm{~S}$ values). However, only small amounts of 18:3(n-3) and 18:2(n-3), which are markers of consumption of live eelgrass, were detected in the lipids of this mollusk. The ratio of 18:3(n-3) and 18:2(n-3) to non-NMI acids $\left(\mathrm{C}_{20}\right.$ and $\mathrm{C}_{22}$ PUFAs) was also low -0.17 . This ratio was much higher (up to 1.22) in lipids of animals feeding on seagrass blades (Nichols et al. 1986). This may be because L. squalida assimilates $Z$. marina organic matter via intermediate links in the microheterotrophic community. A significant part of the organic carbon produced by $Z$. marina leaves was found in epiphytic microheterotrophs (Kirchman et al. 1984). By feeding on these microheterotrophs, epifauna may obtain ${ }^{13} \mathrm{C}$-enriched organic matter void of seagrass marker fatty acids. In such a case, the $\delta^{34} \mathrm{~S}$ values of mollusks would be similar to the $\delta^{34} \mathrm{~S}$ values of seawater or epiphytes. $L$. squalida was the most ${ }^{34} \mathrm{~S}$-enriched among the consumer species.

The fatty acid composition of Littorina squalida reflected the ingestion of several components of the epiphytic community. A high level of 20:5(n-3) in L. squalida was due to feeding on Pneophyllum lejolisii or diatoms. Lipids of $L$. squalida contain large amounts of 20:4(n-6), which is probably derived by the assimilation of some component of the eelgrass blade community besides diatoms and $P$. lejolisii. This component may be a species of fungi rich in 20:4(n-6), many such fungi are encountered on seagrasses (Novak 1984) and may contain high concentrations of 20:4(n-6) (Kim et al. 1998).

Unlike Littorina squalida, the less ${ }^{13} \mathrm{C}$-enriched gastropod Batillaria cumingii (3.6\% of total zoobenthos biomass) was an obligatory bottom dweller. Benthic POM is therefore likely to be the main food source of this consumer. However, B. cumingii was $>3 \%$ more enriched in ${ }^{13} \mathrm{C}$ in comparison to benthic POM or SOM. Thus, it can be presumed that the proportion of ${ }^{13} \mathrm{C}$ enriched Zostera marina organic carbon was higher in $B$. cumingii nutrition than in SOM or benthic POM. $B$. cumingii was significantly (on average $2 \%$ ) depleted in ${ }^{34} \mathrm{~S}$, compared to $Z$. marina leaves and rhizomes $(\mathrm{p}=$ 0.018). Moreover, the main feature of $B$. cumingii lipid composition was an unusually high content of 20:4(n-6) (average 17.1\%). Fungi and protozoa are the most probable components of the microbial community, which may contain high concentrations of 20:4(n-6); furthermore, fungi, bacteria and diatoms can assimilate inorganic sulfur, including some part of the ${ }^{34} \mathrm{~S}$ depleted sulfide from reduced sediment. At the watersediment interface we found no significant numbers of benthic diatoms. There were high levels of bacterial fatty acids in the lipids of $B$. cumingii, including the branched fatty acids typical for sulfate-reducing bacteria; however, the majority of bacteria do not have PUFAs. These indications led us to believe that $B$. cumingii can selectively ingest both fungi and bacteria, which may be important intermediate links between dead $Z$. marina and this deposit feeder. Total contribution of eelgrass carbon to $B$. cumingii nutrition may be very high - up to $57 \%$ (evaluated versus plankton-derived carbon using Eq. 2), but overestimation is probable because neither the proportion of epiphytic algae lost nor ${ }^{13} \mathrm{C}$-fractionation by fungi was considered.

The gastropod Homalopoma sangarense was the most abundant grazer in the studied community, constituting $4.8 \%$ of total consumer biomass. This species was found on seagrass blades only. On the dual $\delta^{13} \mathrm{C} / \delta^{34} \mathrm{~S}$ isotope plot $H$. sangarense falls into both overlapping areas determined by eelgrass and epiphytes or eelgrass and plankton (Fig. 2). Estimates of 
the Zostera marina contribution to $H$. sangarense carbon varied from $38 \%$ (evaluated versus epiphytes) to $71 \%$ (evaluated versus suspended POM).

The most striking features of the fatty acid composition of Homalopoma sangarense were a high content of 18:1(n-7), comparable with the concentration of this acid in Pillucina pisidium, which bears symbiotic bacteria, and a high 18:1(n-7)/18:1(n-9) ratio (Table 5). The $H$. sangarense, which belongs to the more primitive Archaeogastropoda with brush-like radula, can probably obtain the bulk of eelgrass organic matter via selective feeding on epiphytic bacteria. Bacteria were important among the microheterotrophs using the organic matter of Zostera marina (Kirchman et al. 1984). Bacterial production was high enough to meet most of the trophic requirements of $H$. sangarense (Kharlamenko \& Lysenko 1991a). High content of 20:4(n-6) in H. sangarense may indicate an important contribution of fungi to grazer nutrition, as in the case of L. squalida.

The filter feeder Ruditapes philippinarum, found mostly on the periphery of the seagrass meadow, was only slightly ${ }^{13} \mathrm{C}$-enriched compared to plankton (Fig. 2). At the same time, it was much more ${ }^{34} \mathrm{~S}$ depleted than could be expected assuming similarity of the $\delta^{34} \mathrm{~S}$ value of plankton organic sulfur with that of seawater sulfate. Low contribution of Zostera marina $(<4 \%$ ) to $R$. philippinarum food, estimated on the basis of $\delta^{13} \mathrm{C}$ values, cannot explain observed ${ }^{34} \mathrm{~S}$-depletion of the tissues of this mollusk.

Among macroconsumers of the eelgrass meadow, only Ruditapes philippinarum had the high concentrations of 22:6(n-3) characteristic of zooplankton (Table 6). Mollusks of this species can consume a variety of food items, including zooplankton (Sorokin \& Giovanardi 1995), and the correspondence of the $R$. philippinarum fatty acid composition to the fatty acid composition of its food has been shown (Albentosa et al. 1996). This mollusk showed a high content of branched fatty acids, especially iso- and anteiso17:0, which are characteristic of sediment bacteria (Fig. 3E). It suggests that $R$. philippinarum assimilated a notable amount of bacteria from resuspended sediment. Contribution of ${ }^{34}$ S-depleted bacteria, inhabiting reduced sediment, to $R$. philippinarum nutrition could be high enough to result in the observed depletion of ${ }^{34} \mathrm{~S}$ in mollusks.

The bivalve mollusk Macoma incongrua constituted the predominant part $(72.9 \%)$ of total consumer biomass in the eelgrass meadow of Novgorodskaya Bight. The highest population density and the use of 2 feeding modes (filter feeding and surface-deposit feeding) differentiate $M$. incongrua from other bivalves of the eelgrass community.

Macoma incongrua contained much less 22:6 (n-3), typical for zooplankton, than filter-feeding Ruditapes philippinarum $(\mathrm{p}=0.003)$. We therefore conclude that this mollusk obtained food mainly from the watersediment interface or from bottom sediment. However, the $\delta^{13} \mathrm{C}$ values of $M$. incongrua were on average $4 \%$ greater than those of benthic POM. This mollusk was at least $13 \%$ more depleted in ${ }^{34} \mathrm{~S}$ than eelgrass. Moreover, $M$. incongrua is one of the most ${ }^{34} \mathrm{~S}$-depleted species in comparison to other marine or estuarine animals (Peterson et al. 1986, Currin et al. 1995). With the exception of mollusks with symbiotic sulfur bacteria (Conway et al. 1989), only Polymesoda erosa, the mangrove intertidal bivalve, had a $\delta^{34} \mathrm{~S}$ value $(-4.3 \%$ ) (Newell et al. 1995) similar to $M$. incongrua, but only $5 \%$ lower than mangrove leaves. It could be supposed that other unsampled primary producers or microheterotrophs, which assimilated ${ }^{34}$ S-depleted reduced sulfur from interstitial waters, were important in the $M$. incongrua diet.

We can exclude benthic diatoms as an important ${ }^{34} \mathrm{~S}$ depleted primary food source for Macoma incongrua: $\delta^{34} \mathrm{~S}$ values lower than those known to occur in the most ${ }^{34} \mathrm{~S}$-depleted benthic microalgae (+3.9 to $+5.4 \%$, Currin et al. 1995, Stribling \& Cornwell 1997), relatively small amounts of 20:5(n-3) and low 16:1(n-7)/ 16:0 ratio lipids (Fig. 3B) do not confirm the importance of live diatoms in the diet of this consumer. Moreover, microscopic examination did not reveal notable amounts of benthic microalgae in surface sediment or in samples of benthic POM from the eelgrass community studied.

The microbial food chain, based on bacteria and fungi that are capable of assimilation of ${ }^{34} \mathrm{~S}$-depleted sulfide from reduced sediments, can be assumed to be the most probable source of ${ }^{34} \mathrm{~S}$-depleted organic matter for Macoma incongrua. However, no apparent indication of preferential assimilation of some particular component of the microbial community, bacteria, fungi or protozoa, can be inferred from the fatty acid composition of consumer tissues.

Thus, we can suppose that eelgrass, epiphytes and plankton remain the main primary sources for the detritus food chain, supporting the deposit feeder Macoma incongrua. Maximal contribution of Zostera marina organic carbon to $M$. incongrua was $64 \%$, evaluated using $\delta^{13} \mathrm{C}$ values of eelgrass leaves versus suspended POM as endmembers in Eq. (2). The most conservative case, using $\delta^{13} \mathrm{C}$ values of eelgrass leaves versus epiphytes, gives minimal $Z$. marina contribution to $M$. incongrua of $38 \%$.

The dominant mollusk, Macoma incongrua, seems to be the species which can directly assimilate large portions of eelgrass organic matter as detritus. The benthic microbial food chain, based on mixed detritus of plankton, epiphytes and eelgrass, also plays an important part in $M$. incongrua nutrition as a protein-rich 
source. Lipid markers of specific food sources are less pronounced in this consumer, reflecting a more diverse spectrum of food items than in other consumer species of the Zostera marina community. The use of several food sources by animals at the upper level of the detritus food chain is quite justified. Bacteria, which provide the first live link in the detritus food chain, are fairly inactive during the greater part of the year, because of the low water temperature in this area of the sea (Kharlamenko \& Orlova 1990, Kharlamenko \& Lysenko 1991a). Seagrass detritus and bacteria lack a number of essential fatty acids and amino acids. The use of several food sources compensates for these drawbacks in the detritus food web.

In conclusion, based on $\delta^{13} \mathrm{C}$ data, eelgrass carbon plays an important role as a food resource for the dominant consumers in the Zostera marina community of Novgorodskaya Bight. At least 4 of the 6 animal species dominating the biomass, including the gastropods Littorina squalida, Homalopoma sangarense, Batillaria cumingii and the most abundant surface-depositfeeding bivalve Macoma incongrua, derived on average ca $50 \%$ of their carbon from eelgrass.

The eelgrass carbon was only of minor importance for filter-feeding bivalves: Ruditapes philippinarum fed mainly on suspended POM, and Pillucina pisidium derived its carbon mainly from chemoautotrophic endosymbionts. Both these findings were supported by characteristic fatty acid markers.

The fatty acid analysis showed that none of the consumer species studied directly assimilated fresh organic matter of eelgrass. Interspecific variations of both the fatty acid compositions and the sulfur isotope ratios of consumers suggest that there is a variety of pathways, frequently complex, by which eelgrass organic matter reaches invertebrates at lower trophic levels of the community food web. In the case of epifaunal grazers, fatty acid markers showed that epiphytic bacteria (for Homalopoma sangarense) or eukaryotic microorganisms (for Littorina squalida) were the most important links between eelgrass and grazers. The fatty acid markers were much less pronounced in deposit feeders, reflecting an absence of prevailing kinds of food items.

The $\delta^{34} \mathrm{~S}$ data turned out to be of limited use for calculation of the contributions of different primary sources to the Zostera marina community food web, despite negligible trophic fractionation of sulfur isotopes (Peterson et al. 1986). Comparison of $\delta^{34} \mathrm{~S}$ data and fatty acid markers in consumers allows us to suppose that heterotrophic microorganisms at the base of the detritus food web could change, to various degrees, the isotopic composition of organic sulfur flowing through the food web, due to assimilation of inorganic sulfur with different ${ }^{34} \mathrm{~S}$ contents.
As a result, the $\delta^{34} \mathrm{~S}$ data allow recognition of consumers with a high contribution of sulfur-oxidizing chemoautotrophic bacteria (symbiont-bearing Pillucina pisidium) in their diets and those with a major proportion of heterotrophic microorganisms from reduced bottom sediment. In the community studied, depositfeeding Macoma incongrua showed the most pronounced $\delta^{34} \mathrm{~S}$ signal, which indicated utilization of ${ }^{34} \mathrm{~S}$ depleted links from the detritus food web; however, fatty acid composition of this consumer did not show a high content of the fatty acid markers specific for bacteria. Notable contribution of benthic bacteria to the filter feeder Ruditapes philippinarum was confirmed by both the $\delta^{34} \mathrm{~S}$ data and the bacterial fatty acid markers.

Further progress in food web studies of seagrass ecosystems using the complex of multiple SIRA and fatty acid analysis is possible based on the analysis of separate components of the seagrass epiphytic community and micro- and meiobenthic organisms inhabiting surface sediments.

Acknowledgements. This study was supported by the Russian Fund for Fundamental Research, 96-04 49923. We express appreciation to T. I. Shibaeva for assisting in fatty acid analysis. Special thanks to A. V. Ignatev for his contribution to stable isotope analysis. The manuscript was improved greatly by the comments of 4 anonymous reviewers.

\section{LITERATURE CITED}

Ackman RG, Tocher CS, McLachlan J (1968) Marine phytoplankter fatty acids. J Fish Res Board Can 25:1603-1620

Albentosa M, Labarta U, Fernandez-Reiriz MJ, Perez-Camacho A (1996) Fatty acid composition of Ruditapes decussatus spat fed on different microalgae diets. Comp Biochem Physiol 113A: 113-119

Bligh EG, Dyer WJ (1959) A rapid method of total lipid extraction and purification. Can J Biochem Physiol 37:911-917

Canuel EA, Cloern JE, Ringelberg DB, Guckert JB (1995) Molecular and isotopic tracers used to examine sources of organic matter and its incorporation into the food webs of San Francisco Bay. Limnol Oceanogr 40:67-81

Carreau JP, Dubacq JP (1978) Adaptation of a macroscale method to the micro-scale for fatty acid methyl transesterification of biological lipid extracts. J Chromatogr 151: 384-390

Cary SC, Vetter RD, Felbeck H (1989) Habitat characterization and nutritional strategies of the endosymbiont-bearing bivalve Lucinoma aequizonata. Mar Ecol Prog Ser 55: $31-45$

Chanton JP, Lewis FG (1999) Plankton and dissolved inorganic carbon isotopic composition in a river-dominated estuary: Apalachicola Bay, Florida. Estuaries 22:575-583

Christie WW (1988) Equivalent chain-lengths of methyl ester derivatives of fatty acids on gas chromatography. J Chromatogr 447:305-314

Conway N, McDowell Capuzzo JM, Fry B (1989) The role of endosymbiotic bacteria in the nutrition of Solemya velum: evidence from a stable isotope analysis of endosymbionts and host. Limnol Oceanogr 34:249-255 
Conway N, McDowell Capuzzo JM (1991) Incorporation and utilization of bacterial lipids in the Solemya velum symbiosis. Mar Biol 108:277-291

Currin CA, Newell SY, Paerl HW (1995) The role of standing dead Spartina alterniflora and benthic microalgae in salt marsh food webs: considerations based on multiple stable isotope analysis. Mar Ecol Prog Ser 121:99-116

Deegan LA, Garritt RH (1997) Evidence for spatial variability in estuarine food webs. Mar Ecol Prog Ser 147:31-47

DeNiro MJ, Epstein S (1978) Influence of diet on the distribution of carbon isotopes in animals. Geochim Cosmochim Acta 42:495-506

Dornblaser M, Giblin AE, Fry B, Peterson BJ (1994) Effects of sulfate concentration in the overlying water on sulfate reduction and sulfur storage in lake sediments. Biogeochemistry (Dordr) 24:129-144

Duarte CM (1989) Temporal biomass variability and production biomass relationship of seagrass communities. Mar Ecol Prog Ser 51:269-276

Erwin JA (1973) Comparative biochemistry of fatty acids in eucaryotic microorganisms. In: Erwin JA (ed) Lipids and biomembranes of eucaryotic microorganisms. Academic Press, New York, p 42-143

Fenchel T (1977) Aspects of decomposition of seagrasses. In: McRoy CP, Helfferich C (eds) Seagrass ecosystems: scientific perspective. Marcel Dekker, New York, p 195-234

Findlay RH, Trexler MB, Guckert JB, White DC (1990) Laboratory study of disturbance in marine sediments: response of a microbial community. Mar Ecol Prog Ser 62:121-133

Fry B, Sherr EB (1984) ${ }^{13} \mathrm{C}$ measurements as indicator of carbon flow in marine and freshwater ecosystems. Contrib Mar Sci Univ Tex 27:13-47

Fry B, Scalan RS, Winters JK, Parker PL (1982) Sulfur uptake by salt grasses, mangroves and seagrasses in anaerobic sediment. Geochim Cosmochim Acta 46:1121-1124

Fry B, Macko SA, Zieman JC (1987) Review of stable isotope investigation of food webs in seagrass meadows. Fla Mar Res Publ 42:189-209

Gearing JN, Gearing PJ, Rudnick DR, Requejo AG, Hutchins MJ (1984) Isotopic variability of organic carbon in a phytoplankton-based, temperate estuary. Geochim Cosmochim Acta 48:1089-1098

Gillian FT, Hogg RW (1984) A method for estimation of bacterial biomass and community structure in mangrove associated sediments. J Microbiol Methods 2:275-293

Hemminga MA, Mateo MA (1996) Stable carbon isotopes in seagrasses: variability in ratios and use in ecological studies. Mar Ecol Prog Ser 140:285-298

Kayama M, Araki S, Sato S (1989) Lipids of marine plants. In: Ackman RG (ed) Marine biogenic lipids, fats and oils. Vol 2. CRC Press, Boca Raton, Florida, p 3-48

Kharlamenko VI, Lysenko VN (1991a) Productional processes and the role of microheterotrophs in Zostera marina communities. In: Kafanov AI (ed) Ecosystem research: coastal communities of Peter the Great Bay. USSR Academy of Sciences Far East Branch, Vladivostok, p 6-16

Kharlamenko VI, Lysenko VN (1991b) Primary production and microbial destruction of organic matter by epiphytic organisms in Zostera marina ecosystems of the Sea of Japan. In: Kafanov AI (ed) Ecosystem research: coastal communities of Peter the Great Bay. USSR Academy of Sciences Far East Branch, Vladivostok, p 17-30

Kharlamenko VI, Orlova TY (1990) Seasonal variations of bacterio- and phytoplankton in Zostera marina communities. In: Kasyanov VL (ed) Biology of marine plankton. USSR Academy of Sciences Far East Branch, Vladivostok, p 25-29
Khotimchenko SV (1993) Fatty acids and polar lipids of seagrasses from the Sea of Japan. Phytochemistry 33:369-372

Kikuchi T (1980) Faunal relationships in temperate seagrass beds. In: Phillips RC, Mc Roy CP (eds) Handbook of seagrass biology. Garland SPTM Press, New York, p 225-245

Kim H, Gandhi SR, Moreau RA, Weete JD (1998) Lipids of Haliphthoros philippinensis: an oomycetous marine microbe. J Am Oil Chem Soc 75:1657-1665

Kirchman DL, Mazzella L, Alberte RS, Mitchell R (1984) Epiphytic bacterial production on Zostera marina. Mar Ecol Prog Ser 15:117-123

Kiyashko SI, Kharlamenko VI, Imbs AB (1998) Stable isotope ratios and fatty acids as food source markers of depositfeeding invertebrates. Biol Morya (Vladivost) 24:169-174

Klump DW, Howard RK, Pollard DA (1989) Trophodynamic and nutritional ecology of seagrass communities. In: Larkum AWD, McComb AJ, Shepherd SA (eds) Biology of seagrasses. Elsevier, Amsterdam, p 394-457

Lebedev EB, Vyshkvartzev DI (1988) Benthic fauna of the Novgorodskaya Bight, Possyet Bay (the Sea of Japan). In: Proc 3rd All-Union Symp Mar Biol, Part 1. Academy of Sciences Ukranian SSR, Kiev, p 223-224

Lebedev EB, Vyshkvartzev DI (1990) Gastropod mollusks of the inward part of the Novgorodskaya Bight, the Possyet Bay (the Sea of Japan). In: Levin VS, Evseev GA (eds) Distribution and ecology of modern and fossil marine organisms. USSR Academy of Sciences Far East Branch, Vladivostok, p 75-78

Levin VS (1987) Methods of analysis of composition and physical properties of marine sublittoral bottom sediments in ecological studies. USSR Academy of Sciences Far East Branch, Vladivostok

Mann KH (1972) Macrophyte production and detritus food chain in coastal waters. Mem Ist Ital Idrobiol Dott Marco Marchi 29:353-383

McClelland JW, Valiela I (1998) Changes in food web structure under the influence of increased anthropogenic nitrogen inputs to estuaries. Mar Ecol Prog Ser 168:259-271

McConnaughey T, McRoy CP (1979) ${ }^{13} \mathrm{C}$ label identifies eelgrass (Zostera marina) carbon in an Alaskan estuarine food web. Mar Biol 53:263-269

McRoy CP, McMillan C (1977) Production ecology and physiology of seagrasses. In: McRoy CP Helfferich C (eds) Seagrass ecosystems: scientific perspective. Marcel Dekker, New York, p 53-87

Mekhtieva VL, Pankina RG, Gavrilov YY (1976) Distributions and isotopic compositions of forms of sulfur in water animals and plants. Geochem Int 13:82-87

Newell RIE, Marshall N, Sasekumar A, Chong VC (1995) Relative importance of benthic microalgae, phytoplankton, and mangroves as sources of nutrition for penaeid prawns and other coastal invertebrates from Malaysia. Mar Biol 123:595-606

Nichols PD, Johns RB, Klumpp DW (1982) Study of food-chains in seagrass communities. 1. Lipid components of the seagrasses Posidonia australis and Heterozostera tasmanica as indicators of carbon source. Phytochemistry 21:1613-1621

Nichols PD, Klumpp DW, Johns RB (1985) Lipid components of the epiphyte material, suspended particulate matter and cultured bacteria from a seagrass, Posidonia australis, community as indicators of carbon source. Comp Biochem Physiol 80B: 315-325

Nichols PD, Johns RB, Klumpp DW (1986) Lipid components and utilization in consumers of a seagrass community: an indication of carbon source. Comp Biochem Physiol 83B: 103-113

Novak R (1984) A study in ultra-ecology: microorganisms on 
seagrass Posidonia oceanica (L) Delile. PSZN I: Mar Ecol 5:143-190

Nriagu JO, Rees CE, Mekhtieva VL, Lein AV, Fritz P, Drimme RJ, Pankina RG, Robinson RW, Krouse HR (1991) Hydrosphere. In: Krouse HR, Grinenko VA (eds) Stable isotopes: natural and anthropogenic sulphur in the environment. SCOPE 43. Wiley and Sons, Chichester, p 177-265

Peterson BJ, Howarth RW, Garritt RH (1985) Multiple stable isotopes used to trace the flow of organic matter in estuarine food webs. Science 227:1361-1363

Peterson BJ, Howarth RW, Garritt RH (1986) Sulfur and carbon isotopes as tracers of salt-marsh organic matter flow. Ecology 67:865-874

Pond DW, Segonzac M, Bell MV, Dixon DR, Fallick AE, Sargent JR (1997) Lipid and lipid carbon stable isotope composition of the hydrothermal vent shrimp Mirocaris fortunata: evidence for nutritional dependence on photosynthetically fixed carbon. Mar Ecol Prog Ser 157:221-231

Rodionov IA, Yushin VV (1991) Procaryotic symbionts in gill cells of bivalve mollusc Pillucina pisidium. Biol Morya (Vladivost) 1:39-46

Ruby EG, Jannasch HW, Deuser WG (1987) Fractionation of stable carbon isotopes during chemoautotrophic grows of sulfur-oxidizing bacteria. Appl Environ Microbiol 53: 1940-1943

Sargent JR, Whittle KJ (1981) Lipids and hydrocarbons in marine food webs. In: Longhurst AR (ed) Analysis of marine ecosystems. Academic Press, London, p 491-533

Sargent JR, Parkes RJ, Mueller-Harvey I, Henderson RJ (1987) Lipid biomarkers in marine ecology. In: Sleigh M (ed) Microbes in the sea. Ellis Horwood, Chichester, p 119-138

Sofer ZU (1980) Preparation of carbon dioxide for stable carbon isotope analysis of petroleum fractions. Anal Chem 52:1389-1391

Sorokin YI, Giovanardi O (1995) Trophic characteristics of the manila clam (Tapes philippinarum Adams and Reeve). ICES J Mar Sci 52:853-862

Stephenson RL, Tan FC, Mann KH (1986) Use of stable carbon isotope rations to compare plant material and potential consumers in a seagrass bed and a kelp bed in Nova Scotia, Canada. Mar Ecol Prog Ser 30:1-7

Editorial responsibility: Otto Kinne (Editor), Oldendorf/Luhe, Germany
Stribling JM, Cornwell JC (1997) Identification of important primary producers in a Chesapeake Bay tidal creek system using stable isotopes of carbon and sulfur. Estuaries 20:77-85

Sullivan MJ, Moncreiff CA (1990) Edaphic algae are an important component of salt marsh food-webs: evidence from multiple stable isotope analyses. Mar Ecol Prog Ser 62:149-159

Tenore KR, Hanson RB, McClain J, MacCubin AE, Hodson RE (1984) Changes in composition and nutrition value to a benthic deposit feeder of decomposing detritus pool. Bull Mar Sci 35:299-311

Thayer GW, Parker PL, La Croix MW, Fry B (1978) The stable carbon isotope ratio of some components of an eelgrass, Zostera marina, bed. Oecologia 35:1-12

Trust BA, Fry B (1992) Stable sulphur isotopes in plants: a review. Plant Cell Environ 15:1105-1110

Volkman JK, Bavor HJ, Gillan FT, Johns RB, Perry GJ (1980) Microbial lipids of an intertidal sediment. 1. Fatty acids and hydrocarbons. Geochim Cosmochim Acta 44: $1133-1143$

Vyshkvartzev DI, Peshekhodko VM (1982) Mapping out the dominating species of aquatic plants and analysis of their role in the ecosystem of shallow water inlets of Posyet Bay, Sea of Japan. In: Kafanov AI, Levin VS, Fadeev VI (eds) Underwater hydrobiological investigations. USSR Academy of Sciences Far East Branch, Vladivostok, p 120-130

Zhakin AV, Kiyashko SI (1991) ${ }^{13} \mathrm{C} /{ }^{12} \mathrm{C}$ ratios and the origin of organic carbon in the bottom sediments of Possjet Bay, the Sea of Japan. Biol Morya (Vladivost) 5:67-75

Zhukova NV, Kharlamenko VI (1999) Sources of essential fatty acids in the marine microbial loop. Aquat Microb Ecol 17:153-157

Zhukova NV, Kharlamenko VI, Svetashev VI, Rodionov IA (1992) Fatty-acids as markers of bacterial symbionts of marine bivalve mollusks. J Exp Mar Biol Ecol 162:253-263

Zieman JC, Wetzel RG (1980) Productivity of seagrasses: methods and rates In: Phillips RC, Mc Roy CP (eds) Handbook of seagrass biology: an ecosystem perspective. Garland STPM Press, New York, p 86-116

Submitted: June 18, 1999; Accepted: January 9, 2001 Proofs received from author(s): August 29, 2001 